This report was prepared as an account of work sponsored by an agency of the United States

Government. Neither the United States Government nor any agency thereof, nor any of their employees, makes any warranty, express or implied, or assumes any legal liability or responsibility for the accuracy, completeness, or usefulness of any information, apparatus, product, or process disclosed, or represents that its use would not infringe privately owned rights. Reference herein to any specific commercial product, process, or service by trade name, trademark, manufacturer, or otherwise does not necessarily constitute or imply its endorsement, recommendation, or favoring by the United States Government or any agency thereof. The views and opinions of authors expressed herein do not necessarily state or reflect those of the United States Government or any agency thereof.

\title{
Social and Institutional Evaluation Report for Greater-Than-Class C Low-Level Radioactive Waste Disposal
}

\author{
Thomas L. Anderson \\ Barbara E. Lewis \\ Kyle H. Turner, Ph.D. \\ Martha A. Rozelle, Ph.D.
}

Published October 1993

Dames \& Moore, Inc.

1125 17th Street

Denver, CO 80202-2027

\author{
Prepared for EG\&G Idaho, Inc. \\ Under Subcontract No. C90-132741-032 \\ and for the \\ National Low-Level Waste Management Program \\ Under DOE Idaho Operations Office \\ Contract DE-AC07-76ID01570
}




\section{DISCLAIMER}

Portions of this document may be illegible in electronic image products. Images are produced from the best available original document. 


\begin{abstract}
This report identifies and characterizes social and institutional issues that would be relevant to the siting, licensing, construction, closure, and postclosure of a Greater-ThanClass C low-level radioactive waste (GTCC LLW) disposal facility. A historical perspective of high-level radioactive waste (HLW) and LLW disposal programs is provided as an overview of radioactive waste disposal and to support the recommendations and conclusions in the report. A characterization of each issue is provided to establish the basis for further evaluations. Where applicable, the regulatory requirements of $10 \mathrm{CFR}$ 60 and 61 are incorporated in the issue characterizations. The issues are used to compare surface, intermediate depth, and deep geologic disposal alternatives. The evaluation establishes that social and institutional issues do not significantly discriminate among the disposal alternatives. Recommendations are provided for methods by which the issues could be considered throughout the lifecycle of a GTCC LLW disposal program.
\end{abstract}





\section{SUMMARY}

This evaluation of social and institutional issues for a Greater-Than Class-C (GTCC) waste disposal project was performed by Dames \& Moore, in Denver, Colorado, for the EG\&G Idaho, Inc. National Low-Level Waste Management Program (NLLWMP) as part of an ongoing program evaluation of GTCC waste disposal. This report focuses on three key objectives:

- Identify and characterize social and institutional issues relevant to GTCC waste disposal

- Comparatively evaluate disposal alternatives using the social and institutional issues

- Recommend methods and processes by which the social and institutional issues could be addressed throughout the lifecycle of a GTCC waste disposal program.

Section 1 states the report's purpose and characterizes GTCC waste and three disposal alternatives: surface, intermediate depth, and deep geologic.

Section 2 provides basic programmatic assumptions used in the performance of the evaluations.

Section 3 provides a historical perspective of past and current HLW and LLW disposal programs. The discussions establish that social and institutional issues have been commonly omitted from siting activities. The evaluations also conclude that the failure to adequately incorporate consideration of social and institutional issues into a HLW or LLW project can be demonstrated as a contributing factor to the failure of the project.

Section 4 characterizes social and institutional issues that will affect a GTCC waste disposal program. Issue characterization was based on the historical perspective provided by Section 3 , available literature, the experience of the Dames \& Moore authors, and the applicable regulatory language. The issues characterized in Section 4 were then used to evaluate disposal alternatives in Section 5 and to recommend actions for implementation in a GTCC waste disposal program in Section 6.

Section 5 compares each disposal alternative in the context of the social and institutional issues identified in Section 4. The purpose of the evaluation was to determine whether the selection of a disposal alternative would be affected by social or institutional issues. The comparison did not yield significant distinction among the surface, intermediate depth, and deep geologic disposal alternatives. Although the comparisons of disposal alternatives by issues in Section 5 noted some subtle potential differences among the disposal alternatives, none were significant enough to support a choice of one alternative over the others. Further, because the impact of a GTCC waste disposal facility would vary significantly among different locations, even the subtle differences noted could be nonissues for a given location.

Section 6 presents recommendations for addressing social and institutional issues throughout the lifecycle of a GTCC waste disposal program. The five categories of recommendations are:

- $\quad$ Address Issues Through Siting Criteria

- Develop an Impact Alleviation Plan

- Develop a Public Education and Involvement Program

- Use Good Management Practices 
- Establish an Institutional Framework.

Within each category of recommendation, methods and processes are provided by which the issues identified in Section 4 could be successfully integrated into the conduct of a GTCC waste disposal program. The recommendations draw significantly from the successes and failures of the HLW and LLW programs, the experiences of the authors who were involved in radiological waste disposal programs, and from the open literature. 


\section{CONTENTS}

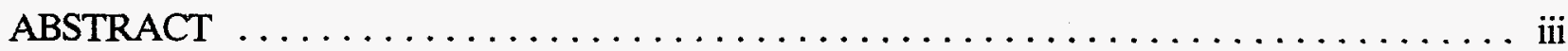

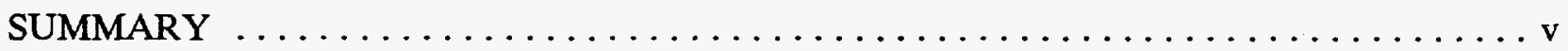

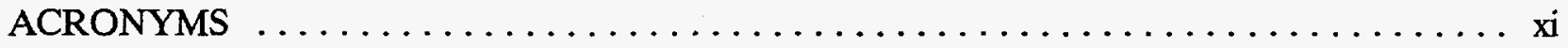

1. INTRODUCTION $\ldots \ldots \ldots \ldots \ldots \ldots \ldots \ldots \ldots \ldots \ldots \ldots \ldots \ldots \ldots \ldots \ldots \ldots \ldots \ldots$

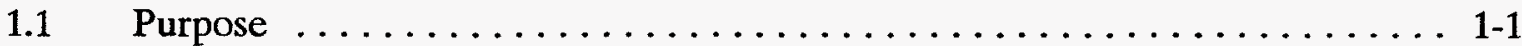

$1.2 \quad$ Background $\ldots \ldots \ldots \ldots \ldots \ldots \ldots \ldots \ldots \ldots \ldots \ldots \ldots \ldots \ldots \ldots \ldots \ldots \ldots \ldots \ldots, 2$

1.2.1 Characteristics of Greater-Than-Class C

Low-Level Waste ........................ 1-2

1.2.2 Greater-Than-Class C Low-Level Waste

Disposal Alternatives ................. 1-3

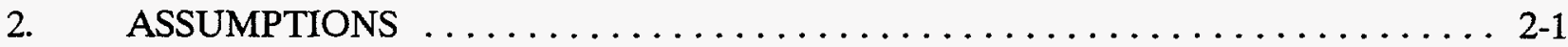

3. HISTORICAL PERSPECTIVE OF RADIOACTIVE

WASTE DISPOSAL PROGRAMS $\ldots \ldots \ldots \ldots \ldots \ldots \ldots \ldots \ldots \ldots \ldots, 3-1$

3.1 Past Approaches to High-Level Waste Disposal Programs . . . . . . . . . . 3-1

3.2 Lessons Learned From High-Level Waste Disposal Program . . . . . . . . . 3-2

3.3 Past Approaches to Low-Level Waste Disposal Programs . . . . . . . . . . 3-4

3.4 Lessons Learned From Low-Level Waste Disposal Programs $\ldots \ldots \ldots \ldots$. 3-7

4. CHARACTERIZATION OF SOCIAL AND INSTITUTIONAL ISSUES $\ldots \ldots .4-1$

$4.1 \quad$ Social and Economic Issues $\ldots \ldots \ldots \ldots \ldots \ldots \ldots \ldots \ldots \ldots \ldots \ldots \ldots \ldots \ldots$

4.1.1 Property Values $\ldots \ldots \ldots \ldots \ldots \ldots \ldots \ldots \ldots \ldots \ldots \ldots, 4$

4.1.2 Local Revenues ......................... 4-4

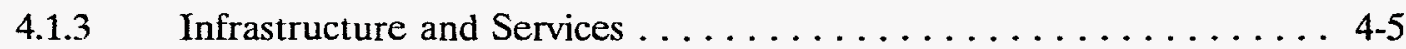

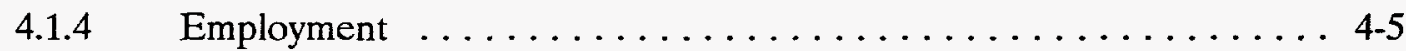

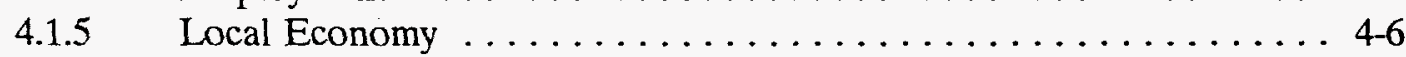

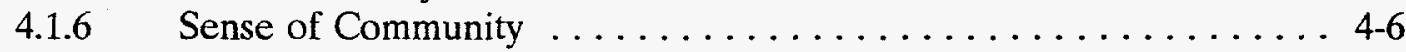

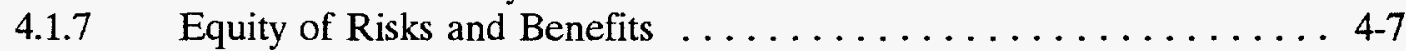

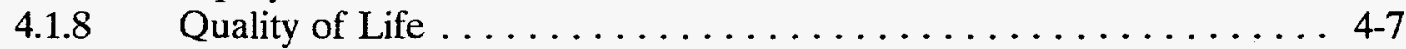

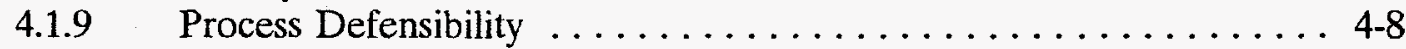

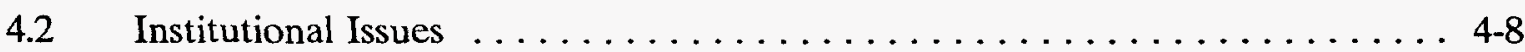

4.2.1 Technical Review Capability $\ldots \ldots \ldots \ldots \ldots \ldots \ldots \ldots \ldots .4 .8$

4.2.2 Adequacy of Regulatory Requirements . . . . . . . . . . 4-8 
4.2.3 Interface of Participants . . . . . . . . . . . . . . . 4-9

4.2.4 Emergency Response Planning . . . . . . . . . . . . . . . . 4-10

4.2.5 Credibility of Participants . . . . . . . . . . . . . . . $4-10$

4.2.6 Land/Water Use and Rights .................. 4-11

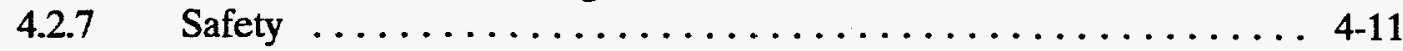

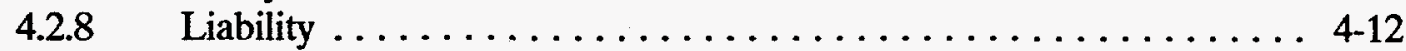

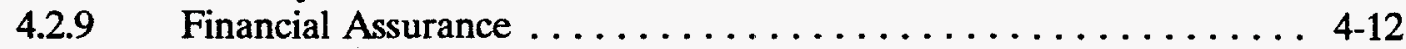

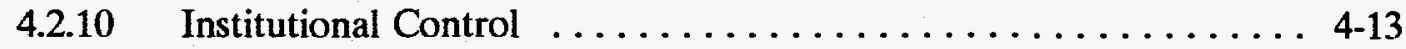

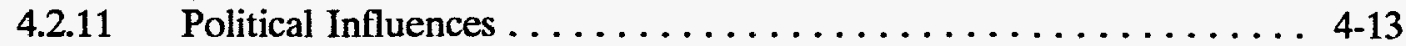

5. COMPARISON OF DISPOSAL ALTERNATIVES BY SOCIAL AND

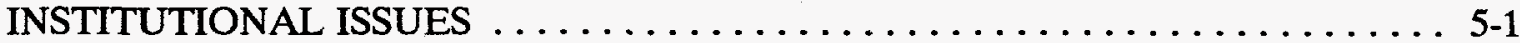

$5.1 \quad$ Social and Economic Issues $\ldots \ldots \ldots \ldots \ldots \ldots \ldots \ldots \ldots \ldots \ldots \ldots \ldots$

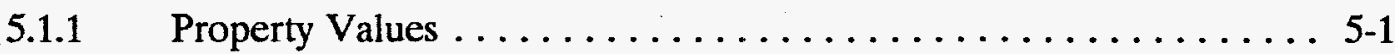

$5.1 .2 \quad$ Local Revenues . . . . . . . . . . . . . . . . . . . . . 5-2

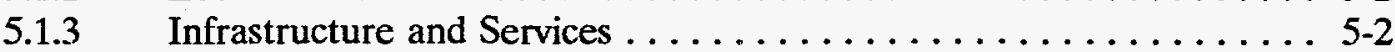

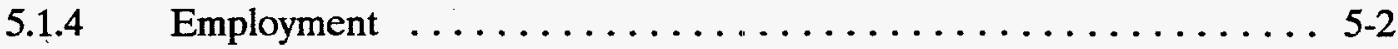

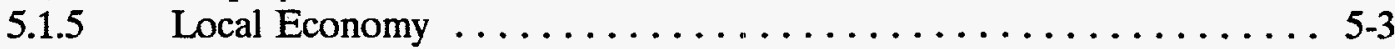

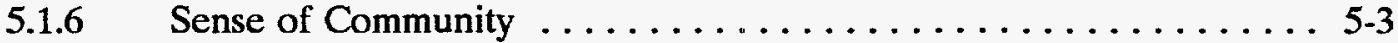

5.1 .7 Equity of Risks and Benefits $\ldots \ldots \ldots \ldots \ldots \ldots \ldots \ldots \ldots \ldots \ldots \ldots \ldots$

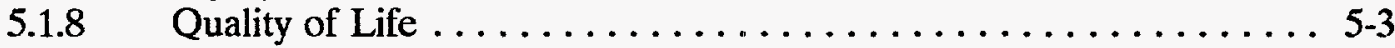

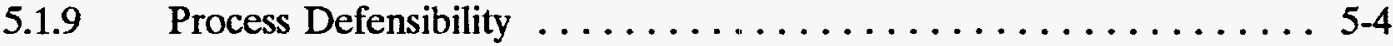

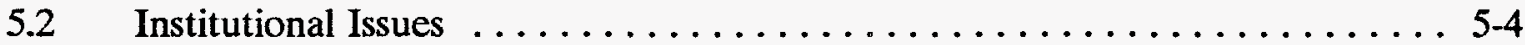

5.2.1 Technical Review Capability $\ldots \ldots \ldots \ldots \ldots \ldots \ldots \ldots \ldots$. . . . . . . .

5.2 .2 Adequacy of Regulatory Requirements $\ldots \ldots \ldots \ldots \ldots \ldots \ldots$. $\ldots \ldots$

5.2.3 Interface of Participants . . . . . . . . . . . . . . . . 5.5

$5.2 .4 \quad$ Emergency Response Planning . . . . . . . . . . . . . . 5-5

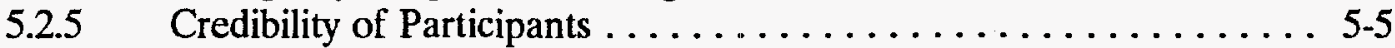

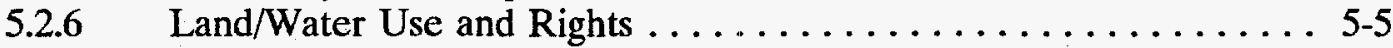

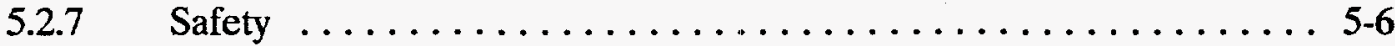

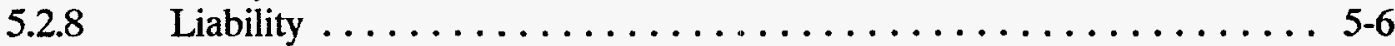

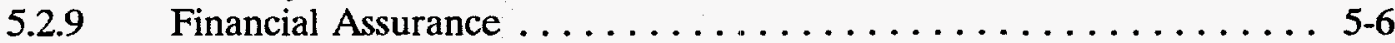

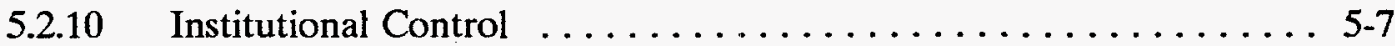

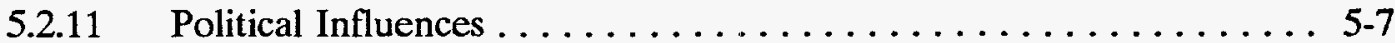

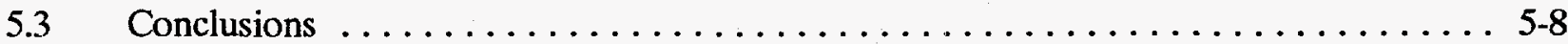

6. RECOMMENDATIONS FOR ADDRESSING SOCIAL AND

INSTITUTIONAL ISSUES $\ldots \ldots \ldots \ldots \ldots \ldots \ldots \ldots \ldots \ldots \ldots \ldots \ldots \ldots \ldots \ldots \ldots \ldots$

6.1 Address Social and Economic Issues Through Siting Criteria ......... 6-2

6.2 Develop an Impact Alleviation Plan $\ldots \ldots \ldots \ldots \ldots \ldots \ldots \ldots \ldots$

6.2.1 Property Values $\ldots \ldots \ldots \ldots \ldots \ldots \ldots \ldots \ldots \ldots \ldots \ldots$ 6-5

$6.2 .2 \quad$ Local Revenues . . . . . . . . . . . . . . . . . 6-5 
6.2.3 Infrastructure and Services $\ldots \ldots \ldots \ldots \ldots \ldots \ldots \ldots \ldots \ldots \ldots$

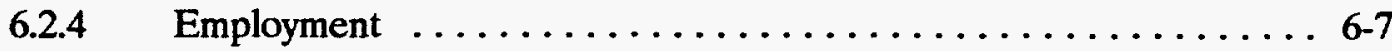

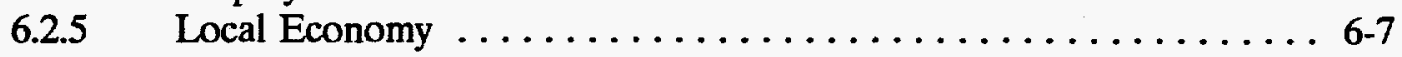

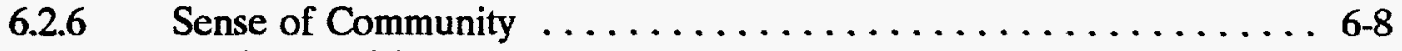

6.2.7 Equity of Risks and Benefits $\ldots \ldots \ldots \ldots \ldots \ldots \ldots \ldots \ldots \ldots .6 \ldots \ldots$

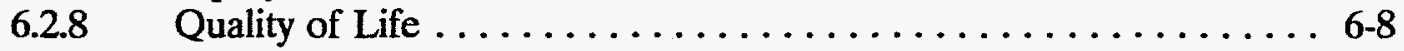

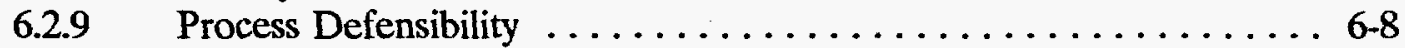

6.3 Develop a Public Education and Involvement Program $\ldots \ldots \ldots \ldots \ldots \ldots$

6.3.1 Public Education . . . . . . . . . . . . . . . . . . . 6-9

6.3.2 Public Involvement $\ldots \ldots \ldots \ldots \ldots \ldots \ldots \ldots \ldots \ldots . \ldots \ldots$

$6.4 \quad$ Use Good Management Practices $\ldots \ldots \ldots \ldots \ldots \ldots \ldots \ldots \ldots \ldots \ldots \ldots$

6.5 Establish an Institutional Framework $\ldots \ldots \ldots \ldots \ldots \ldots \ldots \ldots \ldots \ldots$

6.5.1 Technical Review Capability $\ldots \ldots \ldots \ldots \ldots \ldots \ldots \ldots \ldots$ 6-12

6.5.2 Adequacy of Regulatory Requirements ............. 6-12

6.5.3 Interface of Participants . . . . . . . . . . . . . . . . .

6.5.4 Emergency Response Planning . . . . . . . . . . . . . 6-12

6.5.5 Credibility of Participants ................... 6-12

6.5.6 Land/Water Use and Rights . . . . . . . . . . . . . . . 6-13

$6.5 .7 \quad$ Safety . . . . . . . . . . . . . . . . . . . . 6 6-13

$6.5 .8 \quad$ Liability ............................ 6-13

6.5.9 Financial Assurances $\ldots \ldots \ldots \ldots \ldots \ldots \ldots \ldots \ldots \ldots \ldots \ldots$ 6-13

6.5.10 Institutional Control $\ldots \ldots \ldots \ldots \ldots \ldots \ldots \ldots \ldots \ldots \ldots .14$

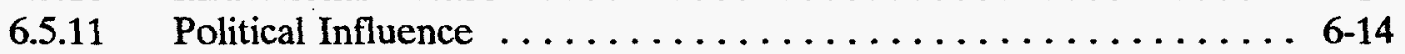

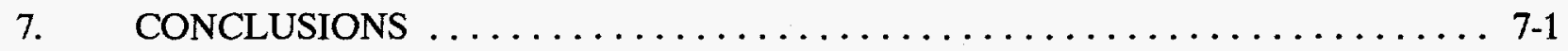

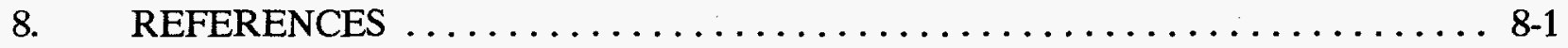




\section{TABLES}

1-1. Characteristics of Greater-Than-Class $\mathrm{C}$ low-level waste $\ldots \ldots \ldots \ldots \ldots \ldots$

1-2. Cost summary of Greater-Than-Class- $\mathrm{C}$ waste disposal alternatives $\ldots \ldots \ldots \ldots$

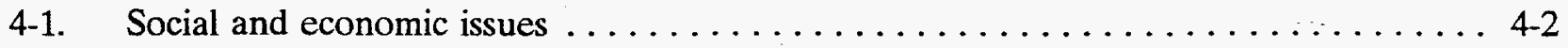

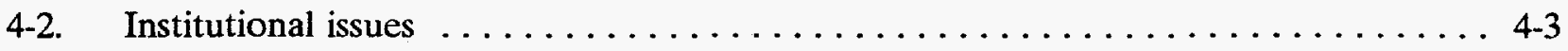

6-1. . Potential siting criteria to address social and economic issues $\ldots \ldots \ldots \ldots$

6-2. Potential impacts alleviation plan components $\ldots \ldots \ldots \ldots \ldots \ldots \ldots \ldots \ldots$ 


\section{ACRONYMS}

\begin{tabular}{|c|c|}
\hline $\begin{array}{l}\text { AEC } \\
\text { AGV }\end{array}$ & $\begin{array}{l}\text { Atomic Energy Commission } \\
\text { aboveground vault }\end{array}$ \\
\hline BGV & belowground vault \\
\hline CFR & Code of Federal Regulations \\
\hline CNSI & ChemNuclear Systems, Inc. \\
\hline DOE & Department of Energy \\
\hline EIS & Environmental Impact Statement \\
\hline EMCV & earth mounded concrete vault \\
\hline EPA & Environmental Protection Agency \\
\hline GTCC & Greater-Than-Class C \\
\hline HLW & high-level radioactive waste \\
\hline IDNS & Illinois Department of Nuclear Safety \\
\hline LLW & low-level radioactive waste \\
\hline $\mathrm{MCC}$ & modular concrete canister \\
\hline MRS & monitored retrievable storage \\
\hline NEPA & National Environmental Policy Act \\
\hline NLLWMP & National Low-Level Waste Management Program \\
\hline NRC & Nuclear Regulatory Commission \\
\hline NWPA & Nuclear Waste Policy Act \\
\hline OTA & Office of Technology Assessment \\
\hline SLB & shallow land burial \\
\hline TRU & transuranic \\
\hline WIPP & Waste Isolation Pilot Plant \\
\hline
\end{tabular}




\section{Social and Institutional Evaluation Report for Greater-Than-Class C Low-Level Radioactive Waste Disposal}

\section{INTRODUCTION}

This report has been generated by Dames \& Moore for EG\&G Idaho, Inc., as a deliverable to the National Low-Level Waste Management Program (NLLWMP). The report provides input to NLLWMP's ongoing evaluation of alternatives for the disposal of Greater-Than-Class C low-level radioactive waste (GTCC LLW) by evaluating social and institutional issues in the context of a GTCC waste disposal program.

In addition to considering social and institutional issues, the NLLWMP is also considering the results of performance evaluations and cost estimates, generated by Rogers \& Associates Engineering Corporation, to formulate a programmatic recommendation for future GTCC waste disposal initiatives.

\subsection{Purpose}

Three key objectives were established by NLLWMP for this evaluation of GTCC waste disposal social and institutional issues. These objectives are:

- Identify and characterize the social and institutional issues relevant to the implementation of a GTCC waste disposal program.

- Comparatively evaluate disposal alternatives using the social and institutional issues as evaluation criteria.

- Recommend that social and institutional issues be considered throughout the lifecycle of a GTCC waste disposal program.

To support these objectives, Section 2 provides the basic assumptions under which the evaluations were conducted and Section 3 provides a historical perspective of the treatment of social and institutional issues during HLW and LLW disposal programs.

Section 4 categorizes and characterizes social and institutional issues. The section provides the foundation on which subsequent applications of the issues are based. The characterization of issues is based on traditional literature definitions as well as programmatic characteristics that developed from the HLW and LLW disposal programs.

Section 5 evaluates the relative favorability of surface, intermediate depth, and deep geologic disposal alternatives in the context of their effect on the social and institutional issues characterized in Section 4. The purpose of the evaluation is to determine whether social and institutional issues discriminate among the disposal alternatives.

Section 6 provides recommendations for considering social and institutional issues during siting, licensing, construction, operations, and closure of a GTCC waste disposal facility. The 
implementation of these recommendations, while not a guarantee to a successful GTCC waste disposal program, would avoid many of the problems related to social and institutional issues that have been experienced by the HLW and LLW disposal programs.

\subsection{Background}

The characteristics of GTCC LLW are described below in Section 1.2.1. The disposal alternatives under consideration by the NLLWMP include surface, intermediate depth, and deep geologic. These alternatives are briefly described in Section 1.2.2.

\subsubsection{Characteristics of Greater-Than-Class C Low-Level Waste}

GTCC waste is a form of LLW for which the total activity of radionuclides exceeds the values established in 10 CFR 61.55. This waste is restricted from surface disposal under 10 CFR 61 because it remains harmful to people and the environment after the period of institutional control called for in the regulation. GTCC has existed since 1983 when the regulation established this classification system. The characteristics of technically feasible systems summarized here are addressed in two reports. The first is entitled "Technically Feasible System for the Disposal of Greater-Than Class-C Low-Level Radioactive Waste" (Rogers 1993), and the second is a report by the Congressional Office of Technology Assessment (OTA) entitled "An Evaluation of Options for Managing Greater-ThanClass C Low-Level Radioactive Waste" (OTA 1988).

Most of GTCC waste is expected to come from reactor decommissioning, although medical sources currently comprise most of the waste now being held in storage. Other sources include fuel manufacturers and test facilities, sealed source manufacturers and distributors, and carbon-14 manufacturers. The characteristics of GTCC LLW are summarized on Table 1-1, extracted from ERM-PMC et al. 1992.

Table 1-1. Characteristics of Greater-Than-Class C low-level waste.

\begin{tabular}{lll}
\hline \multicolumn{1}{c}{ Waste Form } & \multicolumn{1}{c}{ Composition } & \multicolumn{1}{c}{ Radionuclides of Interest } \\
\hline Activated Metals & $\begin{array}{l}\text { Structural components, } \\
\text { replacement parts } \\
\text { Process Waste }\end{array}$ & Ni-59, Ni-63, Nb-94, C-14 \\
& $\begin{array}{l}\text { Wet wastes from cleanups, } \\
\text { filter media, ion exchange } \\
\text { resins }\end{array}$ & $\begin{array}{l}\text { Cs-137, I-129, Tc-99, Sr-90, } \\
\text { Ni-63, TRU }\end{array}$ \\
Contaminated Solids & $\begin{array}{l}\text { Plastics, paper, cloth, glass, } \\
\text { wood, metal }\end{array}$ & TRU \\
Sealed Sources & $\begin{array}{l}\text { Single radionuclide of } \\
\text { relatively high concentration }\end{array}$ & $\begin{array}{l}\text { TRU (Am-241, Cm-244, } \\
\text { Pu-238, Pu-239) or Cs-137, } \\
\text { Sr-90, depending on source } \\
\text { type }\end{array}$ \\
\hline
\end{tabular}

As of 1988 , about $14,000 \mathrm{ft}^{3}$ of GTCC waste were in storage, with an annual generation rate of about $1,400 \mathrm{ft}^{3}$. This is less than $1 \%$ of the annual generation of other types of $L L W$. After the year 2000 , the generation rate of GTCC is projected to increase due to expected reactor decommissionings or refurbishment. In 1988, the OTA report to Congress projected the amount of GTCC in storage by 2020 to be $4.79 \mathrm{E}+3 \mathrm{~m}^{3}\left(1.7 \mathrm{E}+5 \mathrm{ft}^{3}\right)$, with $2.97 \mathrm{E}+3 \mathrm{~m}^{3}\left(1.05 \mathrm{E}+5 \mathrm{ft}^{3}\right)$ generated from reactors, 
and $1.82 \mathrm{E}+3 \mathrm{~m}^{3}\left(6.50 \mathrm{E}+4 \mathrm{ft}^{3}\right)$ from other sources (OTA 1988). Reassessment by Department of Energy (DOE) since the 1988 OTA review currently estimates the volume of GTCC waste generated by 2035 to be $3.25 \mathrm{E}+03 \mathrm{~m}^{3}\left(1.15 \mathrm{E}+05 \mathrm{ft}^{3}\right)$ (Rogers 1993).

\subsubsection{Greater-Than-Class C Low-Level Waste Disposal Alternatives}

GTCC waste disposal alternatives consist of land disposal at three different depths. These disposal depths are:

- Surface $(<30$ meters $)$

- Intermediate (100 to 300 meters)

- Deep geologic ( $>1,000$ meters).

Confinement in any of these engineered land disposal facilities may be accompanied by highly engineered waste packages intended to further improve the waste confinement characteristics of the integrated disposal system. Current estimates of land requirements range from 100 to 130 acres for all disposal alternatives (Rogers 1993).

Construction of facilities and disposal structures are estimated to require 3 years. Actual waste disposal would occur over 20 years from 2035 to 2055 . Closure and stabilization would require about 2 years, leading up to the 100-year period of institutional control (Rogers 1993).

The costs for surface, intermediate, and deep geologic disposal are summarized in Table 1-2, which is a compilation of cost data provided in the Rogers 1993 report. For all alternatives, the costs for construction include the associated costs for site selection, site characterization, production of the Environmental Impact Statement (EIS) and all permitting activities, engineering design, and actual construction of the facility. Operating costs include all conceivable expenditures associated with operating the facility over its planned life. Closure and postclosure costs include those items needed to close the facility and monitor it over the required period of institutional control.

Table 1-2. Cost summary of Greater-Than-Class-C waste disposal alternatives.

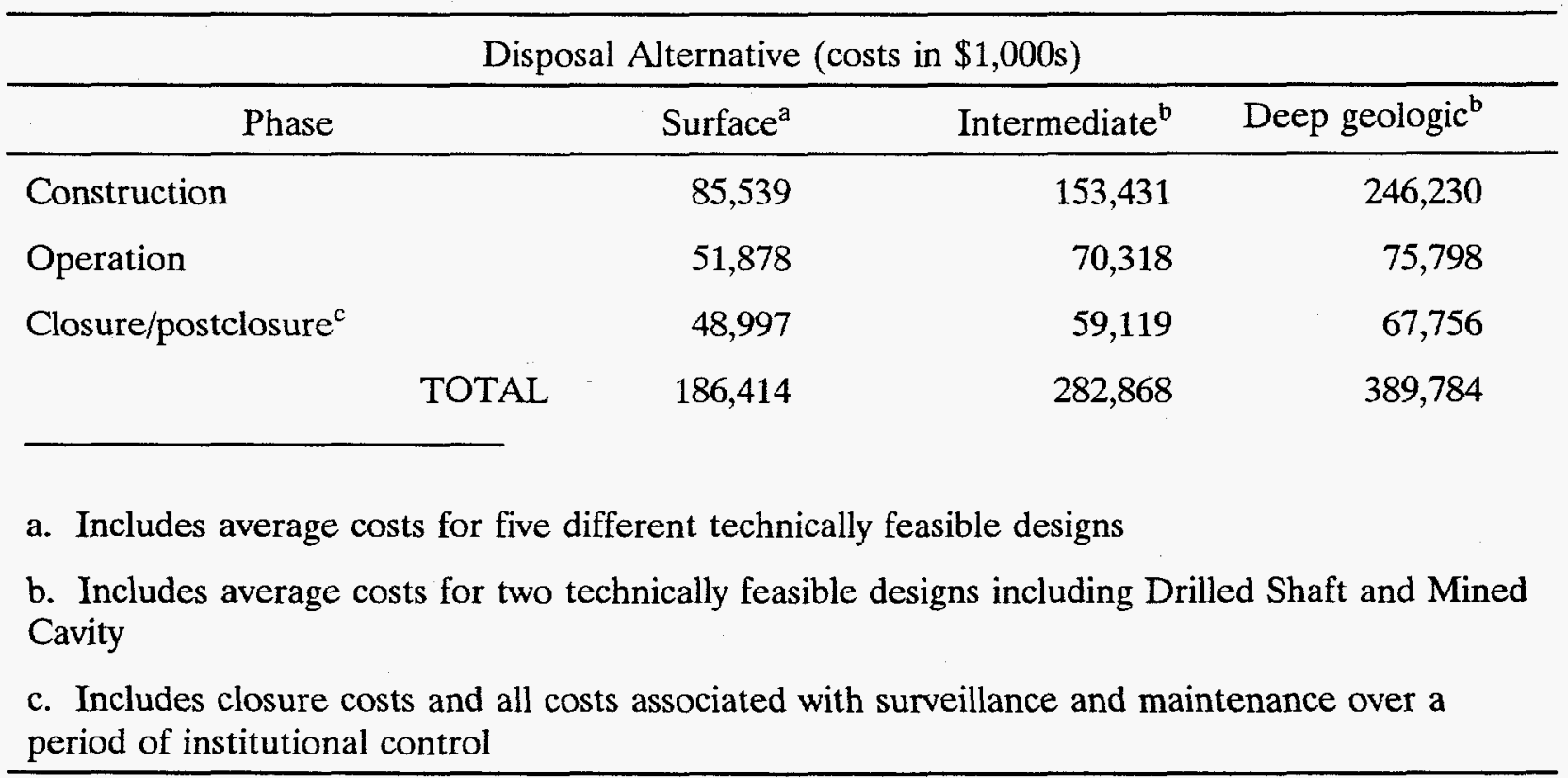


Surface Disposal - Surface disposal is disposal at $30 \mathrm{~m}$ or less. Design techniques evaluated by Rogers \& Associates for disposal facilities that do not exceed this depth include shallow land burial (SLB), belowground vault (BGV), modular concrete canister (MCC), aboveground vault (AGV), and earth mounded concrete vault (EMCV). Costs for construction of these facilities vary directly with the degree to which the facilities are engineered. Although the average life cycle cost for all designs (including construction, operation, closure, and postclosure) is approximately $\$ 186$ million, this alternative is the least expensive of the technologically feasible alternatives. The range of life cycle costs for the five surface designs is $\$ 162$ million to $\$ 210$ million (Rogers 1993).

Intermediate Depth Disposal - Intermediate depth disposal, at levels from 100 to $300 \mathrm{~m}$, involves two general approaches to waste burial. The first employs a drilled hole concept to reach the appropriate depth. The second technique employs a mined cavity concept, which is considerably more expensive. Taken together, the average life-cycle costs for the two designs total approximately $\$ 283$ million, which is nearly $30 \%$ more than surface disposal.

Deep Geologic Disposal - The deep geologic disposal option features burial at depths in excess of $1,000 \mathrm{~m}$. The facility designs for this disposal method are the same as for intermediate depth disposal, employing a drilled hole concept or a mined cavity concept. As would be expected, increased depth results in increased cost. The average life cycle cost of the deep geologic disposal option is approximately $\$ 390$ million, which is $38 \%$ higher than intermediate depth disposal, and $109 \%$ higher than surface disposal.

Various waste package types are included in these estimates. These packages confine the waste in various shielded matrix configurations, and are intended to protect the health and safety of the public during placement, improve the performance characteristics of the repository during its life, or both. These waste packages are discussed in more detail in the 1993 Rogers study. The cost associated with their use are included in the estimates provided in Table 1-2. 


\section{ASSUMPTIONS}

The preparation of this report was based on past trends of the HLW and LLW disposal projects, the experiences of the Dames \& Moore authors as participants in HLW and LLW disposal projects, and a few programmatic assumptions. The following are the programmatic assumptions that helped create the perspective from which conclusions and recommendations were generated:

- Evaluations assume a GTCC waste disposal project entirely independent of the Yucca Mountain HLW Repository Program

- Existing HLW and LLW disposal regulations (10 CFR 60 and 61) will be applicable to GTCC

- GTCC waste must be disposed in a facility licensed by the Nuclear Regulatory Commission (NRC)

- DOE will be the owner and licensee of a GTCC waste disposal facility

- Commercial GTCC waste would be disposed in the facility

- DOE will be responsible for the design and implementation of a site selection process

- DOE will be responsible for the postclosure institutional control period

- DOE would employ a management and operating contractor to implement a GTCC waste disposal project. 


\section{HISTORICAL PERSPECTIVE OF RADIOACTIVE WASTE DISPOSAL PROGRAMS}

This section discusses the following topics:

- Past approaches to HLW disposal programs

- Lessons learned from HLW disposal programs

- Past approaches to LLW disposal programs

- Lessons learned from LLW disposal programs.

\subsection{Past Approaches to High-Level Waste Disposal Programs}

The solution to disposing of HLW in the United States has defied permanent solution for more than 50 years. Potential solutions have been buffeted, redirected, and, all too frequently, terminated as a complex mix of social and institutional issues influenced technical siting programs. At one time or another, virtually every conceivable constituency has concerned itself with the problem of HLW disposal, and, while there has been widespread consensus that disposal is technically feasible, the inability to resolve institutional and social issues has frustrated all efforts to provide permanent disposal capability.

A broad spectrum of institutional approaches has been attempted through the years in selecting, licensing, and operating a HLW geologic repository. Given that a geologic repository is a likely candidate for GTCC waste disposal, experience gained from the HLW program should be a rich source of information on institutional and social issues. Because these issues are most important in siting, the breadth of this experience can be illustrated with a few examples of siting approaches that have been applied to the HLW disposal program.

- Decide-announce-promote site selection process of a Kansas salt mine in 1970 (Clark 1987). This process was conducted almost entirely within the Atomic Energy Commission (AEC), and work was begun at the site with little or no public notification.

- Site selection for the first HLW repository, conducted in the mid-1980's. This program addressed a suite of about a dozen potential sites, several of which were mandated to be on Federal land. The degree of public involvement, as well as the mission of the program itself, was modified midstream by the Nuclear Waste Policy Act (NWPA) of 1982. The program included an increasing level of public involvement, but was constrained by a decision process that was perceived as deviating from the newly evolving site selection criteria. Combined with opposition generated by the second repository program, this perceived deviation from published selection criteria contributed to the legislative decision to mandate a site selection via the NWPA Amendments Act of 1987.

- Site selection for the second HLW repository (Crystalline Repository Program) under NWPA. This site selection was conducted on the basis of a rigorous, ground-up screening procedure that relied heavily on well-defined screening criteria applied using state-of-the-art technology. Public involvement was explicitly incorporated in defining the screening procedure, as well as in reviewing and commenting on the results of the screening. Both phases of public input were accomplished through workshops that included both program personnel and representatives of affected state governments and Indian tribes. Combined with the first HLW repository results, political opposition resulting from opposition at several of the 
selected sites contributed to the termination of the second HLW repository program in the NWPA Amendments Act of 1987.

- Site selection by legislative mandate. In the NWPA Amendments Act, Congress mandated selection of the Yucca Mountain site in Nevada as the only site for which further characterization work would be done. This obviated all technical, institutional, and social criteria and created considerable consternation in the state of Nevada itself, bringing the issues of states' rights into the process. Feeling understandably as though the facility had been forced on the state, Nevada opposed the program and blocked characterization work at the site until a recent court order. Although considerable progress has been made in improving public attitudes, the program has been in a reactive mode in responding to public and political concerns, and, as a result more than six years have passed with minimal progress toward site characterization.

- Volunteer selection of disposal site adopted for the monitored retrievable storage (MRS) facility. This concept, also established in the NWPA 1987 Act, provided for a federal negotiator who could provide financial incentives for states or Indian tribes who volunteered an MRS site. Although several grants for study have been made, a volunteered site has not, as yet, been selected for siting an MRS. Two counties in South Dakota attempted to proceed, but their efforts were vetoed at the state level.

\subsection{Lessons Learned From High-Level Waste Disposal Program}

Given the extreme variation in factors affecting the HLW disposal program and the fact that a site has not yet been formally approved or a facility developed, caution must be used in drawing conclusions from the institutional and social experience flowing from it. In examining the program from this perspective, several authors (Clark 1987 and Slovic, et al. 1991) have analyzed the program and have postulated "lessons learned" over the years. These experiences, along with some that have become widely accepted within the program itself (most of these are being implemented into the ongoing planning and site characterization process at Yucca Mountain) are listed below.

- To conduct a successful siting and licensing program, a consensus must exist among the stakeholders and interested parties that the facility is clearly needed. While this seems an obvious precursor, participants must be prepared to deal with realistic alternatives in accomplishing a given end product. Clearly establishing the need prevents parties from diverting the decision process. Consistently, the HLW disposal program has been characterized as critical to the country, both to maintain viability of the nuclear energy and to provide final disposal for some defense wastes. However, years have passed with no observable ill effects on the public from the lack of HLW disposal capability, and nuclear utilities have begun to license onsite spent fuel storage. Also, projected operation dates for the repository have been rescheduled because of institutional barriers to site characterization. These events do not support the stated need, nor the program's ability to involve serious stakeholders. Since much of the extant regulatory language points to geologic disposal for GTCC waste, establishing another repository to include GTCC (for example, not Yucca Mountain) could encounter similar problems with need justification and stakeholder support.

- There must be meaningful involvement of the public in the decisionmaking processes affecting the design and location of a HLW repository. This involvement must incorporate clear, open communications from the program itself and must provide ample opportunities for interested parties to supply their own input to the program. Perhaps the most frequent public concern 
regarding the HLW program has been that public input has not been integrated into the conduct of the project. These concerns have typically caused a lack of confidence in the decision process and the program. This has led to an unsupportive atmosphere where progress has been delayed.

- An aura of apprehension pervades the public's attitudes towards the process of radioactive waste management. This apprehension derives from the secrecy of nuclear weapons development and testing, and an awareness of the destructive capacity of such weapons. The public's anxiety has been further inflamed by what the public believes has been deliberate misinformation and mismanagement of defense radioactive wastes. Each new HLW disposal program initiative has, in effect, started with the added burden of negative public opinion when going to the public for input. Future HLW programs will have to reverse this preexisting attitude before progress can be made on the program itself.

- Decision processes about HLW disposal must be straightforward enough to be easily understood by the public. Highly sophisticated processes, even though technically comprehensive, proved more of a frustration than a help in certain phases of the HLW disposal program; first because they proved difficult to explain (leading to public suspicion that the process is deliberately obscured to enable manipulation); and second, because disintuitive results were obtained. Decision processes and implementation techniques should therefore be explicitly designed with the public interaction process in mind.

- Providing a combined decision process/public involvement framework that provides for meaningful input from all stakeholders is exceedingly difficult, in part because of the large number and varied agendas of interested parties. For example, on the Crystalline Program, considerable interface with representatives of state government was maintained throughout the selection process; however, at workshops presenting siting results, it was clear that the lay public felt that these officials represented an official state position and not that of the public. To put this challenge into perspective, a list of important stakeholder groups follows:

- Nuclear Control groups (for example, Natural Resources Defense Council)

- State and local officials in site and transportation states

- Landowners and the general public in site and transportation areas

- State and local officials in states where spent fuel and radioactive wastes are accumulating

- Public Utility Commissions

- Utility ratepayers

- Utilities and their stockholders

- Nuclear industry interests

- National environmental and antinuclear groups

- Local political action and opposition groups. 


\subsection{Past Approaches to Low-Level Waste Disposal Programs}

In 1980, Congress adopted the Low-Level Radioactive Waste Policy Act. This Act, which was amended in 1985, stated that the three licensed LLW disposal facilities in the United States capable of accepting the country's LLW would remain operational until December 31, 1992. The Act also declared that each state government is obligated to establish a program ". . . to provide for the safe management of low-level radioactive wastes produced within its borders ..." and that such a program ". . provide for the management of these wastes in the safest manner possible." According to the Act, the program can be implemented by individual states, or two or more states can form a regional compact and work together cooperatively.

The original Act, as amended, required all states to achieve specific programmatic goals for managing LLW within a set timeframe, or face severe penalties. These goals were intended to ensure orderly and equitable progress in the development of new LLW disposal facilities across the country. In response to the Act, nine regional compacts were formed, and the remaining states/jurisdictions were working as independent entities. Except for two membership changes, these original compacts remain intact.

All state or regional LLW disposal facilities were to be operational by January 1, 1993. As of May 1993, no new LLW disposal facilities have been constructed. Millions of dollars and labor-hours have been spent on extensive siting studies conducted by several of the compacts and individual states, but no new sites have yet been accepted.

There are three existing LLW disposal sites:

- Beatty, Nevada

- Hanford, Washington

- Barnwell, South Carolina.

Nevada's Beatty LLW Disposal Facility closed December 31, 1992. The Hanford, Washington facility remains operational as the disposal site for the Northwest compact and has permitted access to the Rocky Mountain compact. The states of the Southeast compact have access to the Barnwell facility through January 1, 1996. Agreements have been negotiated permitting three states and six compacts outside the Southeast compact region to have continued access to the Barnwell facility through July 1994, pending milestone compliance. Unaffiliated states and other noncompact jurisdictions are allowed to apply for continued access to Barnwell after January 1, 1993.

A brief review of LLW disposal across the United States will help in understanding the issues that continue to play major roles in the nationwide LLW disposal facility siting process. The following summary was generated from a February 1993 report compiled by the Illinois Department of Nuclear Safety (IDNS), entitled "Low-Level Radioactive Waste Compacts Status" (IDNS 1993). The state printed in bold denotes host state status.

- The Appalachian Compact (DE, MD, PA, WV) is in the midst of its siting process. Three potential sites are to be selected by mid-1994.

- The Central Midwest Compact (IL, KY) is starting its second siting program. During the original program, the entire state of Illinois was screened, and two potential host sites were determined. Following extensive characterization studies, the Martinsville alternative site was recommended. In October 1992, the Compact's LLW Disposal Facility Siting Commission 
met and unanimously rejected the site. Legislation outlining a new siting process was signed by the governor in March 1993.

- In the Central States Compact (AR, KS, LA, NE, OK), a site has been selected and the license application has been under review for more than a year. In May, 1993, the Nebraska Department of Environmental Quality and Nebraska Department of Health indicated an intent to deny the license based on the presence of wetlands on the proposed site. A contested case hearing was requested and granted, and discovery is currently in process. A delay for the original court date of June 8, 1993 has been approved, and no other court date has been set. Several other lawsuits are pending.

- Michigan, the original host state for the Midwest Compact (IN, IA, MN, MO, OH, WI), has left the compact and functions independently. The host state is now Ohio. The State legislature is working with the governor to appoint a "Blue Ribbon Panel" of experts to make recommendations on how to proceed. The panel has not yet been established.

- The two members of the Northeast Compact (CT, NJ), are both host states. In Connecticut, potential site locations were announced in 1991. Plans for siting a temporary storage facility were being pursued; however, a new siting plan was submitted to the Connecticut legislature in April 1993, which determined that no temporary storage facility is needed at this time. In 1992, New Jersey's LLW Disposal Facility Siting Board suspended its previously adopted state-wide screening criteria in favor of a completely voluntary process. A new draft siting plan has not been submitted to date.

- The Northwest Compact (AK, HI, ID, MT, OR, UT, WA, WY) will retain use of the Hanford facility. The Northwest Compact has agreed to accept waste for the Rocky Mountain Compact. Hanford closed its doors to all other compacts and states in December 1992.

- The Beatty, Nevada LLW disposal facility closed on January 1, 1993. Colorado was the original Host State for the Rocky Mountain Compact (CO, NM, NV). However, an agreement was negotiated between the Rocky Mountain Compact and the Northwest Compact permitting the Rocky Mountain Compact access to the regional LLW disposal facility at Hanford. Therefore, a host state is no longer needed for the Rocky Mountain Compact. Wyoming left the Rocky Mountain Compact to join the Northwest Compact.

- The Barnwell, South Carolina facility will stay open until January 1, 1996 for the Southeast Compact (AL, FL, GA, MS, NC, SC, TN, VA). Several other states and compacts have negotiated access agreements with Barnwell through July 1994. In the host state of North Carolina, two sites are currently being characterized, and the site selection process is expected to be complete by mid-1993.

- In the Southwest Compact (AZ, CA, ND, SD), a site was selected in the Mojave Desert and the license application was reviewed. The regulator was near an affirmative decision when an additional public hearing process was requested. It has been recently determined that additional hearings were not necessary; however, an appeal has been filed. During this time, the California Department of Health Services is continuing to process the licensing decision. Two lawsuits (related to endangered species) are still pending. In addition, a land transfer issue is also pending, and agreement for direct purchase is being negotiated. 
- Maine had selected six sites for characterization, but has suspended the process based upon a disposal agreement with Texas. Legislation to approve a compact with Texas was signed on June 9, 1993 and will be issued for a statewide referendum in November of this year.

- Massachusetts is continuing to develop rules and regulations to govern its siting process. Public comment is being received on the siting process.

- Michigan, the original host state for the Midwest Compact, is now independent and has been denied access to presently operating disposal sites. In October 1992, the state legislature established an advisory panel to recommend how to proceed with the State's LLW disposal responsibilities under Federal law. No further progress has been achieved to date.

- Having suffered a failed first siting process in 1990 (which involved intense public protests), New York is revising its siting process. State legislation now requires that a preferred disposal method be determined before engaging in any onsite activities.

- Texas is in the process of evaluating a site in the western part of the State. A 14,000 -acre parcel of land, including the site, has been purchased by the State. A facility could be online by January 1996. Texas has also finalized land disposal agreements with the States of Maine and Vermont.

- Vermont has recently reached an agreement with the State of Texas regarding a disposal agreement. It is anticipated the Governor of Vermont will sign an executive order regarding the disposal agreement, since the Vermont legislature is not in session.

- The four remaining unaffiliated jurisdictions of New Hampshire, Rhode Island, District of Columbia, and Puerto Rico are currently denied access to the existing facilities. They are doing very little about siting, and are primarily attempting to negotiate disposal agreements with other states/compacts. The District of Columbia has stated that it will not site a facility.

Of the eight states/compacts that have actually started siting programs, three have experienced failed first attempts and are starting second programs (New York, Central Midwest Compact, Northeast Compact). Two have actually selected final sites and submitted license applications, but the programs are now stalled due to pending lawsuits (Central States Compact, Southwest Compact).

Maine has selected initial sites to study; the Southeast Compact is characterizing two sites; and in Texas, a final site is being studied. In the remaining areas, use of existing facilities for as long as possible seems to be the preferred option. The siting programs for these remaining areas are in various stages of preliminary implementation or program/criteria development. Most of the states/compacts are also exploring temporary storage facilities.

The basic siting process for all states and compacts follows these general steps:

- Develop screening criteria (exclusionary and favorability factors)

- Conduct state-wide screening

- Determine initial potential host sites

- Conduct additional technical studies

- Select limited number of candidate sites

- Conduct full characterization studies of candidate sites

- Select final site. 
In several areas where the siting process has actually occurred, voluntary host sites have been solicited; however, response has been limited.

In today's society, there is a general lack of trust in almost every aspect of the LLW siting and licensing processes-the regulators, the facility operators, the technology, the safety features, the fairness of the siting process, and the need for the facilities. This, however, was not always the case. The proposed closure of the three operating LLW disposal facilities in the late 1970 s led to the current state of today's nationwide LLW program.

The Barnwell, South Carolina; Beatty, Nevada; and Hanford, Washington facilities were successfully sited, and are now preparing to close or restrict disposal operations. An understanding of the social climate in which these facilities were sited is useful in understanding the critical siting issues of today. The Barnwell site serves as a case study. The facility was sited, licensed, and built in the early $1970 \mathrm{~s}$, ". . . a time, when, nationally, trust in the safety of commercial nuclear power (the main generator of LLW) was still high in most quarters, and when most views of the nation's defense industry were regarded by many as a litmus test for patriotism" (English 1991). It is important to realize that for more than the past four decades, the nuclear industry has played an important role in the socioeconomic character of the area. The Savannah River Site and Allied General Nuclear Services are both located in the county. According to English 1991,

All of this created in Barnwell a climate of belief in the benefits of science and technology, and confidence in those responsible for the management of new technologies. Although this confidence is not necessarily shared throughout Barnwell County . . . it still prevails.

The facility operator was and is ChemNuclear Systems, Inc. (CNSI). CNSI's corporate commitment to being a "good neighbor" helped to foster community feelings of goodwill and trust toward the operator and, therefore, the disposal process. Tax revenues from the facility benefitted the county. To the extent possible, goods and services were locally procured. The majority of employees lived within the county. Local organizations and events received company support. According to English 1991, "Overall, it appears that CNSI has been a net plus socially and economically for many people in Barnwell County. ... It also appears that CSNI is generally held in high regard."

The feelings in Barnwell County are definitely not indicative of the national public sentiment toward LLW disposal facilities today. The current status of the nationwide efforts to site new LLW disposal facilities is testimony to the overall lack of trust in the siting and licensing processes.

\subsection{Lessons Learned From Low-Level Waste Disposal Programs}

Despite advances in disposal technology, state-of-the-art monitoring techniques, and regulatory revisions, public sentiment is one of the largest factors in the siting of any waste disposal facility. In a 1991 article titled "The NIMBY Syndrome: Environmental Failure and Credibility Gap," S. Wright noted "Government officials and industry analysts are now suggesting that the most difficult obstacles to siting hazardous wastes may be socio-political, not technical." There is no evidence of this social trend weakening. According to Wright, "The current impasse over siting raises some important questions about the effectiveness of these government programs, and about confidence in the new regulations and new technologies. Indeed, it even raises questions about the credibility of government agencies and industry to place public health and safety above profits and politics." 
Strong public opposition has been the primary obstacle to site selection for LLW disposal facilities. Although extensive public involvement programs have been implemented, many residents of potential host communities have rallied in very vocal and organized opposition, thus pushing the issue into the political arena. Even though technical and economic feasibility have been proven, and health risk issues have been fully examined and accounted for, public perceptions of the potential harmful effects of such a facility stand in the way of project completion. At this time, the majority of the American public does not feel comfortable in accepting the perceived risk associated with a LLW disposal facility. For almost any host community, the potential economic benefits do not seem to justify the perceived negative impacts on their quality of life.

Inconsistencies with the actual siting and licensing processes seem to be a problematic aspect of the nationwide program as well. While screening criteria for all states/compacts are similar, the specific factors are not consistent. Responsible regulatory agencies during siting and licensing vary from governor-appointed boards to the NRC. Mechanisms vary widely on the spectrum of public input and approval. Some examples of the wide range of variations include:

- Mandated public involvement during siting and licensing to no public involvement requirements

- Statewide advisory councils to local citizen advisory groups

- Voter veto authority to no voter veto authority.

Such programmatic variations make it difficult to measure, much less attain, successful siting programs.

Obviously, never-ending cycles of technical studies and public opposition are cost-prohibitive for any siting project. Even through a pessimistic social atmosphere prevails, facility siting projects have not come to a halt. Many nonnuclear, yet highly controversial facilities, have been sited. The NIMBY (not-in-my-backyard) syndrome can be overcome. The common denominator for successful siting projects has been close, open, and ongoing work with the involved/affected communities from the start of the project. Time-intensive efforts to discuss and resolve the specific social and institutional concerns of the potentially affected community is essential. It is important to understand the specific issues and levels of concern for each area, as they may vary from region to region. Honest and consistent interpersonal relationships must be established and maintained to assist the two-way flow of information. Financial assistance programs for the potential host communities, such as those conducted by the Vermont and Illinois LLW programs, allows the community the opportunity to independently study the social, institutional, economic, and technical issues and information (typically with the help of an independent consultant/firm), and obtain an objective perspective. According to Wright 1991, "... independent research scientists or technical experts may play a key role in providing the public with reliable information upon which decisions can be made." 


\section{CHARACTERIZATION OF SOCIAL AND INSTITUTIONAL ISSUES}

This section identifies social and institutional issues that will be relevant to the lifecycle conduct of a GTCC waste disposal project. These issues are the components of discussions provided in later sections of this report. Each issue is characterized by the elements that most commonly define the issue. Where applicable, the discussion also includes specific references to regulatory requirements, which provide the legal component of the issue.

This section is divided into two subsections, 4.1, Social and Economic Issues, and 4.2, Institutional Issues. The issues lend themselves to some degree of consolidation and, therefore, within each subsection several subtopics are developed. Tables 4-1 and 4-2 summarize the scope of each issue and identify the subsection that contains the discussion. Each issue identified in Tables 4-1 and 4-2 is discussed in detail under Sections 4.1 and 4.2 , respectively.

\subsection{Social and Economic Issues}

For this report, social and economic issues are those issues that characterize the potential effects of a GTCC waste disposal project on the health and welfare of the affected public. The discussions consider both real and perceived areas of impacts and integrate the roles of the various public and institutional participants.

\subsubsection{Property Values}

The effect of a GTCC LLW disposal facility on property values will consist of both perceived and real components. Public perception will reflect reduced values due to the stigma of a GTCC waste disposal facility, while real values will likely increase during construction and operations from the increased work force, and decrease upon closure if employment opportunities are not generated to utilize the operational workers. 
Table 4-1. Social and economic issues.

\begin{tabular}{|c|c|c|}
\hline Section & Issue $^{a}$ & Scope of Discussion \\
\hline 4.1.1 & Property Values & $\begin{array}{l}\text { Property values, public perception, employment, } \\
\text { safety, environmental monitoring }\end{array}$ \\
\hline 4.1.2 & Local Revenues & $\begin{array}{l}\text { Tax revenues, payment in lieu of taxes, economic } \\
\text { benefits, infrastructure, services, economic } \\
\text { diversity, financial assistance, equitable } \\
\text { compensation }\end{array}$ \\
\hline 4.1.3 & Infrastructure and Services & $\begin{array}{l}\text { Infrastructure, government expenditures, } \\
\text { anticipated costs, induced growth, emergency } \\
\text { response }\end{array}$ \\
\hline 4.1.4 & Employment & $\begin{array}{l}\text { Labor demand, employment, local benefit, hiring, } \\
\text { ancillary industry, job training }\end{array}$ \\
\hline 4.1.5 & Local Economy & $\begin{array}{l}\text { Payroll, direct and indirect income, induced } \\
\text { development, labor availability, cost of living, fixed } \\
\text { income }\end{array}$ \\
\hline 4.1.6 & Sense of Community & $\begin{array}{l}\text { Public perception and participation, social } \\
\text { balance, community cohesion, social stability, in- } \\
\text { migration, growth }\end{array}$ \\
\hline 4.1.7 & $\begin{array}{l}\text { Equity of Risks and } \\
\text { Benefits }\end{array}$ & $\begin{array}{l}\text { Compensation packages, economic benefits, } \\
\text { transient population, risks, benefits, impact on } \\
\text { future generations }\end{array}$ \\
\hline 4.1 .8 & Quality of Life & $\begin{array}{l}\text { Physical disruption, psychological impacts, risk } \\
\text { perception, impacts to future generations }\end{array}$ \\
\hline 4.1.9 & Process Defensibility & $\begin{array}{l}\text { Community attitudes, perception, participants' } \\
\text { credibility, participation of government and public }\end{array}$ \\
\hline
\end{tabular}

a. Each issue is fully described in Section 4.1. 
Table 4-2. Institutional issues.

\begin{tabular}{|c|c|c|}
\hline Section & Issue $^{a}$ & Scope of Discussion \\
\hline 4.2 .1 & $\begin{array}{l}\text { Technical Review } \\
\text { Capability }\end{array}$ & $\begin{array}{l}\text { Regulators, specialized expertise, lack of qualified } \\
\text { participants, public confidence }\end{array}$ \\
\hline 4.2 .2 & $\begin{array}{l}\text { Adequacy of Regulatory } \\
\text { Requirements }\end{array}$ & $\begin{array}{l}\text { Regulations, HLW, TRU, LLW, period of } \\
\text { institutional control, regulatory overlap, credibility, } \\
\text { protection of public health }\end{array}$ \\
\hline 4.2 .3 & Interface of Participants & $\begin{array}{l}\text { Technical, regulatory, political, and public } \\
\text { participation, federal, state, local, and tribal } \\
\text { participation, licensing }\end{array}$ \\
\hline 4.2 .4 & $\begin{array}{l}\text { Emergency Response } \\
\text { Planning }\end{array}$ & $\begin{array}{l}\text { Emergency response planning, transportation } \\
\text { accidents, lack of experience, evacuation } \\
\text { capability, authority }\end{array}$ \\
\hline 4.2 .5 & Credibility of Participants & $\begin{array}{l}\text { Public perception, building credibility, technical } \\
\text { qualifications, proliferation of nuclear waste sites }\end{array}$ \\
\hline 4.2 .6 & $\begin{array}{l}\text { Land/Water Use And } \\
\text { Rights }\end{array}$ & $\begin{array}{l}\text { Fee simple ownership, mining and water rights, } \\
\text { resource controls, adequate safeguards, time } \\
\text { period for institutional controls }\end{array}$ \\
\hline 4.2 .7 & Safety & $\begin{array}{l}\text { Protection of workers and public, public } \\
\text { perception, performance standards, site security } \\
\text { and access controls, intruders, institutional } \\
\text { controls, safety, maintenance }\end{array}$ \\
\hline 4.2 .8 & Liability & $\begin{array}{l}\text { Owner, transporter, and operator responsibility } \\
\text { and liability, financial assurances }\end{array}$ \\
\hline 4.2 .9 & Financial Assurance & $\begin{array}{l}\text { Financial assurance for institutional controls, } \\
\text { resources for operation, closure, decommissioning, } \\
\text { and log-term care, monitoring, maintenance, } \\
\text { inadequacies, public confidence }\end{array}$ \\
\hline 4.2 .10 & Institutional Control & $\begin{array}{l}\text { Environmental monitoring, periodic surveillance, } \\
\text { custodial care, record generation and } \\
\text { maintenance, period of institutional control, site } \\
\text { security and access control, health protection, } \\
\text { public confidence, regulatory authority }\end{array}$ \\
\hline 4.2.11 & Political Influences & $\begin{array}{l}\text { Politicians, public confidence, funding } \\
\text { authorizations, safety, long-term care, financial } \\
\text { sureties, lobbying, participation by agencies and } \\
\text { other impact groups }\end{array}$ \\
\hline
\end{tabular}

a. Each issue is fully described in Section 4.2. 
The perception of effect on property values as an issue is likely to change during the lifecycle of a GTCC facility. In siting and licensing, public concerns regarding potential adverse effects on property values are likely to be significant. A 1980 national poll conducted by Robert Mitchell found that only 10 to $12 \%$ of the American public would voluntarily live a mile or less from either a nuclear power plant or a hazardous waste disposal facility. In a survey of Texas panhandle residents, "more than $40 \%$ of those surveyed believed that a high-level radioactive waste repository in the area would hurt the value of their homes whereas more than $70 \%$ foresaw that farmland values would decline" (Kasperson 1988).

Several factors may affect a facility's impact on property values, including safety record, environmental monitoring, and safety controls. Historically, poor safety and environmental records led to adverse property value impacts (Battelle 1989). In the absence of these adverse factors, property values may be seen to rise overall during construction and operation as the facility increases economic activity in the area. Increased housing demand is likely to increase home values. Some property owners would likely benefit from the rise in property values while others would be adversely affected by it. Adverse effects may be influenced by the extent to which the community becomes stigmatized by people outside the community. The visibility of the facility during operations may also influence property values. A recent survey of residents in Barnwell, South Carolina concluded that CNSI had not negatively affected property values, and may have had a positive impact (English 1991).

Upon closure, the fear will be a decline in values in response to the loss of local employment and reduced revenues. Therefore, proposals to diversify the economy and other measures to mitigate the impact of closure on the local community will be important to the local community.

\subsubsection{Local Revenues}

One measure of how a facility or activity will contribute to the local economy is how much revenue it will generate. Typically, a new project will benefit the community by reducing the tax burden on residents and other businesses in the tax jurisdiction. Sources of local government revenues may include property taxes, fees and charges, special payments, and state aid.

In siting, the value of the facility to the local tax base will be a major benefit. Whether the proposed GTCC land and facility is publicly owned and operated is important to local tax revenues because publicly owned entities are tax-exempt. For a publicly owned facility, the local community receives a package for payment in lieu of taxes. While tax revenues represent an important community benefit, local supporters will need to be careful that this payment in lieu of taxes is not perceived as a bribe. Facility siting can create a rift within the local community between those who favor the economic benefits of the facility and those who feel that supporters are selling out the health of the community and its residents for short-term economic gain.

In construction and the early phases of operation, payments in lieu of taxes, disposal fees, and other special payments and fees will be the primary sources of revenue to the local community. At the same time, the community will need to invest in additional infrastructure and services required to respond to the facility operations and associated growth. The key issue at this point will be the extent to which the compensation package provides adequate revenues for these up-front investments.

During operation, growth resulting from the facility will result in increased tax revenues. Additionally, since most state aid is provided to local governments on a per capita basis, population growth induced by the facility will result in increased state aid. 
Upon closure, the key issue will be how closure of the facility as a source of tax revenues will affect taxes for remaining residents and businesses. The challenge will be to enhance the economic diversity of the community during operation so that the effect of facility closure will be mitigated.

Increases in government revenues resulting from taxes or payments in lieu of taxes, disposal fees, surcharges, and other special sources of revenues, as well as direct payments that would result from a GTCC facility may be viewed as indirect financial assistance to the population potentially impacted by the project. Frequently, however, financial compensation to those directly or indirectly impacted by such projects is controlled or limited by county, state, or Federal agencies remotely located from the affected project location. The issue of financial compensation for those impacted by the project is further complicated by the difficulty involved in assessing real versus perceived impact and determining equitable compensation.

\subsubsection{Infrastructure and Services}

The establishment of a GTCC disposal facility has the potential to require support from the local community in excess of existing infrastructure and services capacity. The impact of increased demand on infrastructure and services, such as schools, roads, sanitary systems, housing, and community and social services, vary based on the community's existing capacity. The larger the community, the more likely their ability to absorb the increased demands without impact. The fiscal impacts of such increased demand can be significant on the local public if impact assessment and mitigation plans are not implemented early.

Additional local government expenditures resulting from the facility must be weighed against the additional local revenues projected. In siting, the principle concern is whether the projected revenues exceed anticipated costs and whether revenues are accrued before costs are incurred. Estimates for the CNSI facility in Barnwell, South Carolina found that increased estimated expenditures were approximately 5\% lower than traditional tax revenues from the facility. Of the $\$ 2.1$ million in revenues, all but $\$ 743,354$ were associated with special charges for the facility, including the business license tax, the special surcharge, and the radwaste tax (English 1991).

Most expenditures will be per capita expenditures associated with the growth induced by the facility during construction and operation. For a GTCC disposal facility, these costs are not expected to be substantial since total employment will not be large. Additional costs may include emergency response capability and improvements in transportation access. In closure, because the local community will want to be assured that it will not be burdened with any long-term monitoring costs, financial sureties from the DOE will be important.

\subsubsection{Employment}

Employment impacts will include those arising from the facility's demand for labor, the demand for labor on the part of firms supplying goods or services to the facility, and employment generated by expenditures of indirect income. The extent to which the jobs are important locally will depend upon the unemployment rate in the area and how much local residents benefit from them. In siting and construction, important factors will include the number and type of jobs, the length of the construction and operational periods, and the employment policies of the developer. Commitments to hiring local residents will be important. Since local jobs tend to the manual or unskilled, the local community or area may also be interested in training for more skilled positions. 
Another potential benefit during facility operation is the attraction of ancillary industrial and research facilities, such as has occurred at Barnwell, South Carolina (English 1991). In addition, employment associated with a GTCC facility will be relatively stable during operation compared to cyclical industries like manufacturing and mining. Facility employment can serve as a buffer when downswings in the local economic base occur.

With facility closure, loss of employment will be an important local concern. Economic development and job training programs will be important to provide mechanisms for people and jobs to stay in the local economy.

\subsubsection{Local Economy}

Direct income gains from the facility will include both payroll and nonpayroll expenditures. Nonpayroll expenditures include equipment and vehicle purchases and maintenance, facility maintenance and administration, legal services, etc. Indirect income will result from expenditures made with the direct income, or the spending and respending of this income in the local economy.

In siting and licensing, the local area will be primarily concerned with projections of direct and indirect income generated by the facility over the life of the project. During construction and operation, commitments to local purchases will be important since typically only a small portion of nonpayroll expenditures directly benefit the host community. The area will also benefit from induced development, such as ancillary facilities for waste packaging or research. On the other hand, the increased employment may reduce labor availability in other parts of the local economy, increasing the cost of living. This may adversely affect farmers, persons living on fixed incomes such as the elderly, and small businesses who face increased labor costs, as well as other small businesses who face increasing competition from larger chains as the population grows (Kasperson 1988). When the facility is closed, the area will lose income associated with the facility itself and other spin-off industries.

Some businesses may be more adversely affected by the stigma effect of the disposal facility than others. For instance, in South Carolina, a food processing plant did not locate in the area because of the proximity to the disposal facility. However, measuring the opportunity cost of facility siting in terms of potential lost business is difficult.

\subsubsection{Sense of Community}

Numerous, often conflicting factors can influence the community's sense of social balance as a result of facility siting. These factors result from the effect of the siting effort on the community or the influx of workers to the area. Concerning the effect of the siting effort, attitudes vary and may polarize the community into pro and con factions. This polarization can erode community cohesion, create conflict between different socioeconomic groups, diminish confidence in political and social leaders, and adversely affect the area's self-image.

While siting is generally disruptive to social stability, involvement in a constructive siting process can be positive, leading to community empowerment. The effects of the siting effort on the local area will generally diminish with time, but some adverse effects on the sense of community may be permanent. 
During construction, the major social impact will be from the influx of construction workers. Workers temporarily residing in the local area can be disruptive to the community. In general, the smaller and more cohesive the local community and the more remote the site, the more significant the impacts of in-migration.

During operation, the influx of permanent newcomers may alter the social structure of the community. Instability and tensions may result if the social characteristics of the newcomers (education, income, religion, ethnicity) are different from those in the local area. The size and composition of local government may change. Cultural traditions, community values, and political power may also change. Growth may also lead to community unrest, indicated by increased crime or social problems. At the same time, growth may provide new opportunities for self-development. Key factors affecting the impact of growth include the levels of project-related growth, the settlement patterns of the in-migrants, and the timing of growth.

\subsubsection{Equity of Risks and Benefits}

How the risks and benefits of a facility are distributed locally and nationally substantially impacts local attitudes toward a GTCC facility. In siting, local attitudes will be influenced by whether the siting process is viewed as open and fair. Compensation packages will be assessed for whether they provide adequate benefits to the local community. Equity concerns within the community are likely if residents near the site perceive that their interest is being "sacrificed" to obtain economic benefits for others. Siting in a small community may not result in much local growth if a larger community is nearby. Similarly, during construction, one community may receive up-front funds while another incurs the adverse effects from the influx of a transient population. Population shifts resulting from facility closure may also lead to equity concerns.

The issue of equity of risks and benefits may also take on an additional dimension - time. Typically, direct and indirect compensation for real and perceived impacts of facilities similar to a GTCC facility are distributed during the life of the project as defined by construction operations and closure. During the institutional control phase and beyond, the physical presence of such a facility may impact the local community even if facility performance meets all design requirements to protect the public. In the unlikely event of a failure at the facility, the potential impact on future generations would be the driving factor in prioritizing remediation activities and determining fair compensation for damages. This future impact perspective will be an issue for a GTCC facility as early as the siting phase.

\subsubsection{Quality of Life}

Quality of life impacts can be defined as the effect on the potential for residents to feel that they can live a healthy and contented life. Given this definition, they include both physical disruption in the community and psychological impacts. Physical disruption includes noise, traffic, and disruptions of views. Psychological impacts included anxieties over perceived risks to personal safety and health. The literature on risk perception indicates that many factors in addition to the calculated risk of occurrence influence how people view risks. Risks that are perceived as being greater are those that are involuntary, unknown, dreaded (or stigmatized), and inequitable.

Quality of life concerns are generally greatest during the siting process and construction when the most physical disruption is occurring. However, experience at other sites, such as Barnwell, South Carolina, suggest that, for some people, concerns about health risks will remain throughout operation and into closure and beyond. Even though the protection limits and performance standards 
established by regulations are and will be developed to ensure the long-term safe performance of the disposal facility, the concern for impacts to future generations will be an emotional and technical basis for objections to the project.

\subsubsection{Process Defensibility}

Community attitudes toward a GTCC facility are influenced by people's perceptions of the decisionmaking process. Do they believe that sound technical decisions are being made? Do they have an influence on decisions that may affect them personally or as a community? While this issue is most sensitive in the siting process, community oversight in construction, operation, and closure is important to securing local satisfaction that their interests are being safeguarded. Local demands to be involved in decisionmaking have grown in response to perceived inadequacies in the technical and siting decision process for a broad spectrum of potentially hazardous facilities, such as LLW, HLW, hazardous waste disposal facilities, landfills, etc.

Public perception of the process and of the individuals or organizations involved as advocates for any project perceived as less than desirable are affected by the knowledge base from which their opinions are derived. For a GTCC project, the combination of radioactivity, waste, and a Federal program will predictably trigger significant negative connotations by the potentially affected public. The very determination of whether a specific member of the public would be affected by a proposed GTCC facility will be shaped more by the public's perception than fact. Participation by the affected public in the decisionmaking process can enhance understanding of technical issues and also lead to personal relationships among the participants leading to interaction on a less emotional and more factual basis.

\subsection{Institutional Issues}

For this report, institutional issues are those that result from the interactions among the organizations which formally or informally participate in the decisionmaking regulatory process regulatory agencies, local and regional government, the disposal applicant, and other interested parties.

\subsubsection{Technical Review Capability}

Regulation of a GTCC disposal facility will require regulators with specialized expertise. Since not all states and few localities will have the experts in-house, accessibility to both national and international expertise may be important. The lack of qualified local and, perhaps, state personnel may also become a factor influencing the local community's confidence in the program.

During siting, technical review capability is primarily an issue of public confidence. In construction and operation, it also becomes a logistical and financial problem to provide for adequate facility oversight.

\subsubsection{Adequacy of Regulatory Requirements}

Lack of specific regulatory requirements governing the disposal of GTCC LLW is a potential institutional constraint. The regulations in 10 CFR 61.55(2)(iv) imply a requirement to employ deep geologic disposal in accordance with 10 CFR $60, " .$. unless proposals for disposal of such waste in a disposal site licensed pursuant to this part are approved by the Commission (NRC)." This 
language puts an added institutional burden upon DOE to justify a fourth radioactive waste disposal program. HLW at Yucca Mountain, transuranic waste (TRU) at the Waste Isolation Pilot Plant (WIPP), and the commercial and state compact LLW programs are the existing radioactive waste programs, all of which are experiencing significant difficulties in their implementation. Because GTCC-specific disposal regulations do not exist, the difficulties experienced by HLW, TRU, and LLW disposal projects could be significantly amplified by a GTCC program.

Many areas of overlap between HLW and LLW regulations must be resolved specifically for GTCC. One potential area of conflict pertains to the period of institutional control. LLW regulations ensure system performance and protection from inadvertent intrusion through an institutional control period that can last as long as 100 years per 10 CFR 61.59(b). HLW regulations rely on system design and depth, as well as an institutional ability to retrieve the waste within 50 years after emplacement to protect against intrusion and ensure performance per 10 CFR 60.111(b)(1). The regulators must resolve this contrast in the institutional control period for GTCC LLW.

If modeled after the existing regulations governing HLW and LLW, 10 CFR 60 and 61 respectively, GTCC regulations would only assess the socioeconomic impacts of construction and operation of a GTCC disposal facility within the context of an EIS. However, adequate compliance with the requirements of the National Environmental Policy Act (NEPA) would neither address all of the issues described within this report, nor mandate the integration of social and institutional issue resolution into the conduct and decisionmaking aspects of a GTCC disposal project.

Beyond the institutional issues regarding GTCC disposal regulations, there exists a potential public concern regarding the adequacy of the regulations and the competence of those responsible for their implementation to protect the public health for both present and future generations. The issue of adequacy is possibly most important in the closure and postclosure stages. Given our limited history in regulating radioactive waste management for the long-term, the likelihood of errors is greater. This in turn affects the confidence people in a host community will have in the ability of the regulatory community to protect the public health.

\subsubsection{Interface of Participants}

Coordination among the different levels of government, the various regulatory bodies, and the individuals and groups representing the public is one of the most difficult tasks associated with a project of the technical and social complexity of a GTCC LLW disposal facility. High performance by all participants requires clear definition of the roles, responsibilities, and limitations of the different players at the local, regional, state, and Federal levels. Recognition of the differing technical, regulatory, political, and emotional perspectives of all of the participants and a respect for their opinions will be the key component of successful program interactions.

It can be anticipated that Federal and state government participants are on opposite sides of such a project regardless of their respective regulatory or institutional responsibility. The HLW repository program serves as a predictive model for a GTCC project. The DOE would be the sole proponent for such a facility. The state and local agencies would be opposed as would the majority of the public. The NRC and Environmental Protection Agency (EPA) would maintain their neutrality, while being viewed by the state and local agencies and the public as being compromised by DOE. The politicians will vary in their intensity, but all will object to siting such a facility in their district. The grass roots level and national groups will lobby at the local, state, and Federal level against the facility. 
The entire process of siting, licensing, operating, and closing a GTCC facility would occur in a climate of distrust that would be somewhat devoid of credibility on the part of all participants. For example, Federal, state, and regional entities have had difficulties in radioactive waste disposal facility siting. From the public's perspective, there would be no clear delineation between the project sponsor and regulator during licensing, construction, and operation. The history of Federal and state oversight for Federal facilities has contributed to the public's lack of confidence in the regulatory community. Public opposition will come in all shapes and sizes and must be fairly dealt with by the proponents if such a project is to succeed.

The specific requirements for state and Indian tribe participation for LLW disposal are defined in 10 CFR 61.70, 61.71 and 61.72. Under these provisions a state or tribal governing body whose interests may be affected by a LLW disposal facility has the right to be involved with the NRC in the licensing process. In their application, the state or tribe must describe how they intend to participate, and may include their intention to promote local government and citizen participation. They may also submit estimates of the type and extent of impacts that they anticipate from a LLW disposal facility.

\subsubsection{Emergency Response Planning}

Effective emergency response capability must be a high priority to protect the workers at the facility and residents of the area. The challenge is to organize a team that knows what to do and can mobilize quickly to respond. The response capability should address transportation accidents as well as operations at the facility. It can be anticipated that the DOE would take the same steps for a GTCC facility as those taken regarding emergency preparedness at other nuclear sites. The planning must involve both project-specific and local elements that would be involved in the execution of any emergency response related to a GTCC facility.

The lack of experience and capability of local emergency response teams to safely deal with transportation accidents involving radioactive materials will be both a local and national concern. Demonstrated emergency response capability by a community will help address concerns about public safety, and could be used as a positive factor during the siting process. For commercial nuclear facilities, the failure to demonstrate emergency evacuation capability in the event of an accident has been a source for successful intervention and delay. Such concerns could easily be addressed during the siting of a GTCC facility. A detailed emergency response plan that included roles, responsibilities, and procedures would probably be a requirement of a GTCC disposal facility license application.

While local officials will need to be involved in emergency response planning, they will also need funding and oversight to take an active role. During operations, the facility will have primary responsibility for emergency response, but will need to maintain active communications with local and state players, and may need to augment their capabilities through equipment purchases and training programs. In closure and postclosure, the issue will shift to the need to maintain a technical and financial capability to respond to an environmental monitoring program that indicates system failure.

\subsubsection{Credibility of Participants}

To gain local acceptance of the facility and minimize the social disturbance brought by the facility to the host area, both the decisionmaking process and project sponsors and regulators must be credible with the general public. Credibility is achieved by involving people in the process. In 1991, a study at Columbia University evaluated the influence of different factors on the public's perception of an individual as credible (Covello 1991). Demonstrated empathy and caring comprised half of the 
overall influence on credibility, while technical competence represented only $15 \%$. Other credibility factors were dedication and commitment, and honesty and openness. During the lifecycle, the issue of credibility evolves from building credibility for the decisionmaking process to demonstrating reliability and responsiveness during operations and closure. By continuing to involve the local community in relevant facility decisions, the facility can build a positive track record.

The issue of the credibility of the DOE and its contractors as implementors of a GTCC program could be enhanced somewhat if the provisions of 10 CFR 61.11(b) were met. These provisions require demonstration to the NRC that the organizational structure is capable of conducting the project and that the participants are technically qualified.

A GTCC disposal facility may have an additional credibility problem if a disposal alternative other than deep geologic is pursued due to the implied regulatory language set forth in $10 \mathrm{CFR}$ 61.55(2)(iv). Some factions may interpret this language as a recommendation for GTCC disposal in the Yucca Mountain HLW repository, because to do otherwise would be a needless proliferation of nuclear waste sites.

\subsubsection{Land/Water Use and Rights}

Land ownership, and mineral and water rights provide a mechanism to control the use of the land, water and subsurface into the future. Since the HLW disposal regulations in 10 CFR 60.121 and the LLW disposal regulations in 10 CFR 61.7(c) and 10 CFR 61.59 state "Disposal of radioactive waste received from other persons may be permitted only on land owned in fee by the Federal or a State government," it is assumed that the DOE, as the responsible agency of the federal government, will maintain fee simple ownership of the land and mining and water rights for the property. Key issues are identifying and implementing restrictions that will adequately safeguard the public health and safety. As previously discussed, another issue for GTCC will be determining the appropriate time period for institutional controls.

In some communities where land availability is limited, facilities requiring substantial land area are controversial. In siting, this issue may be raised by opponents to the project as land is removed from future development or sale. Other land use issues include the commitment of prime or unique agricultural land for the facility and buffer zone, the compatibility of current and projected uses of land in the vicinity of the facility, and consistency with local land use plans.

\subsubsection{Safety}

Safety as a GTCC disposal facility issue relates primarily to the protection of both workers and the public from unacceptable radiation exposures from normal operations and accidents. From the public's perspective, setting adequate exposure limits and providing independent oversight to ensure that they are met are important. Past problems with the management of government-owned radioactive and hazardous waste streams resulted in a skeptical public that questions the adequacy of the regulations as well as the capability of the government to enforce them.

The NRC has quantified adequate public safety regarding LLW disposal in the system performance standards in 10 CFR 61.41 which require that "Concentrations of radioactive material which may be released to the general environment in ground water, surface water, air, soil, plants, or animals must not result in an annual dose exceeding an equivalent of 25 millirems to the whole body, 75 millirems to the thyroid, and 25 millirems to any other organ of any member of the public." Similar standards for protection during operations are in 10 CFR 20. As a issue affecting a GTCC 
disposal project, it must be recognized that much of the public neither accepts these limits as an assurance of adequate safety nor trusts in the capabilities of the regulatory institutions to objectively establish performance requirements that will protect the public safety. The issue is further compounded by the public's mistrust of the scientific community and their performance models, which are used to demonstrate a disposal facility's ability to meet the performance requirements.

Site security and access controls are measures that must be implemented to protect not only the inadvertent intruder from accidental exposure but also prevent the intentional intrusion by an individual or group intent upon project disruption or some form of terrorism. A commitment to, and implementation of, rigorous site security measures throughout the lifecycle of a GTCC waste disposal facility will be a necessary component of a site safety program. As was discussed in Section 4.2.2, "Adequacy of Regulatory Requirements," the longevity of institutional controls as an active element of GTCC disposal site safety maintenance must be resolved by the regulators.

\subsubsection{Liability}

Liability not only defines who is liable, but also, through a clear assignment of liability, acts as a motivator for responsible management. Since it is assumed that DOE will have overall liability for the facility with NRC, state, and EPA oversight, and since the taxpayers foot the bill when the federal government assumes liability, the motivational effectiveness of liability assignment may be questioned. The liability issue also relates to financial assurance, which is discussed in more detail in Section 4.2.9.

During operations, the operator, although under contract to DOE, may assume partial liability. Waste owners and transporters would be responsible for resolving liability during transport to the disposal site. DOE and its operating contractor would probably not assume any liability until the waste arrives onsite and is certified as qualified for disposal.

\subsubsection{Financial Assurance}

Financial assurance includes providing financial resources for operation; closure and decommissioning of the facility; long-term care, including monitoring and maintenance; and monies to cover emergency response and remedial actions in the event of an accident. In preparing the Environmental Impact Statement for 10 CFR 61 (NUREGs -0782 and - 0945), the NRC conducted a review of financial assurance programs and identified inadequacies in the financial assurance pools for LLW. In several instances even when adequate fees were assessed to disposers of LLW, the revenues were not earmarked and, therefore, are not available now for the disposal site closure and long-term monitoring.

The LLW disposal regulations in 10 CFR 61 Subpart E define explicit requirements for financial assurances for site closure, stabilization, and the period of institutional control. These requirements define the process by which adequate assurances will be calculated by the NRC and establishes acceptable forms of financial surety. Because the DOE will be the licensee of a GTCC disposal facility, assurance provisions unique to the Federal government will have to be developed to ensure public confidence that adequate funding will be available for the entire lifecycle of a GTCC disposal facility. 


\subsubsection{Institutional Control}

As stated in the LLW disposal regulations per 10 CFR 61.59(b), an institutional control program must physically control access to the disposal site, and must include ". . . carrying out an environmental monitoring program at the disposal site, periodic surveillance, minor custodial care, and other requirements as determined by the Commission; and administration of funds to cover the costs for these activities. The period of institutional controls will be determined by the Commission, but institutional controls may not be relied upon for more than 100 years following transfer of control of the disposal site to the owner."

The objective of environmental monitoring is to identify any environmental releases so that they can be controlled or remediated to protect the public health. Issues related to environmental monitoring include what is adequate, who is responsible, how often it is conducted and how reliable it is. The public is likely to view the environmental monitoring program as their first line of defense against failure of the GTCC disposal facility. Accordingly, providing assurances that the program is both adequately designed, executed, and funded will be critical to achieving public confidence.

Current LLW regulations, 10 CFR 61.53, require an environmental monitoring program throughout the life of a LLW disposal site, including after closure, to provide "... early warning of release of radionuclides from the disposal site before they leave the site boundary." By contrast, the HLW regulations rely on system performance, and have no explicit environmental monitoring requirements after the repository is closed 50 years after the last waste is emplaced. As has been the case for the Yucca Mountain HLW repository, specific provisions, such as those set forth in Subpart B "Licenses" of 10 CFR 60, will have to be developed between the NRC and DOE to accommodate the licensing process for GTCC to amend the language of 10 CFR 61.7(c)(4), which states that "... the Commission [NRC] lacks regulatory authority over the Department [DOE] for this [LLW disposal] activity."

The LLW waste disposal regulations require that "... for a period of five years, the licensee must remain at the disposal site for a period of postclosure observation and maintenance to assure that the disposal site is stable and ready for institutional control." However, the intent of the regulations is to ensure that ongoing active maintenance of the site is not required during the period of institutional control per 10 CFR 61.7(c).

After site closure and during the period of institutional control, in addition to an active monitoring program, 10 CFR 61 also requires active physical surveillance to restrict site access and custodial care. This regulation in 10 CFR 61.7(c)(4) also allows land uses that would not affect the stability of the site and its ability to protect the public.

The generation and maintenance of detailed operational records for the facility are a mandatory element of the LLW regulations. Subpart G of 10 CFR 61.80 requires such records as location and quantity of radioactive wastes, conditions of wastes upon receipt, repackaging operations, annual reports of liquid and airborne releases, and the results of the environmental monitoring program. Records must be generated and maintained throughout the period of institutional control.

\subsubsection{Political Influences}

Federal, state, and local politicians can have a significant effect on the overall decision process of a GTCC program. Politicians will affect the determination of need, the selection of applicable technology, and most significantly the selection of a site for disposal. In our system, there is a 
tendency for politicians to emphasize controversial facilities as a political tool. This adds to emotionalism in the decision process and makes it more difficult to maintain public confidence.

GTCC disposal funding will depend upon authorizations from Congress. To make a siting effort work, there should be provision for up-front monies both for facility siting, design and construction, and local community benefits. In addition, the influence of politics can affect the availability of funds to conduct safe operations and provide long-term care. Because the public is well aware of the potential for political disruption of funding, the public may demand establishment of financial sureties that are legally protected from future political actions.

The influence of politics on the technical and regulatory process is probably greatest in facility siting. Political lobbying by different areas in the country, major industries, and interest groups can influence the siting process. Even with a legitimate siting process, decisions can and have been amended in the state and Federal political arenas. The history of radioactive waste management in this country includes many examples of changes in congressional direction. It is difficult to develop a credible track record and siting process when it is subject to political action.

Because of the controversial nature of siting a GTCC facility, the siting process is also particularly vulnerable to the influence of community activists in the political arena. While politicians may privately support a particular siting location, public support is considered political suicide. In this climate, with the stigma associated with waste management facilities of all types, achieving a credible and successful siting process will be difficult. 


\section{COMPARISON OF DISPOSAL ALTERNATIVES BY SOCIAL AND INSTITUTIONAL ISSUES}

Social and institutional issues affect the overall success of noxious (real or perceived) facility site selection, construction, and operations. However, historically these have not been employed to select among disposal options for either HLW or LLW disposal concepts. In a few instances, processes have relied on them to contribute to the selection of site locations. For example, one regulatory and philosophical approach established for the siting of an MRS site for HLW begins with an expression of interest on the part of a state, Indian tribe, or other interested party per NWPA, 1982 as amended. The theory is that a voluntary expression of interest demonstrates at least an initial positive reaction to the social and institutional issues relevant to such a facility. However, this approach, to date, has proven no more effective than purely technical approaches to address and resolve the technical, social, and institutional issues of such facilities. As described in Section 3, adequate consideration of social-institutional issues, such as those characterized in Section 4, have been a major factor in the failure of attempts to gain approval of both HLW and LLW disposal sites.

The following sections provide a characterization of social and economic issues in Section 5.1, and institutional issues in Section 5.2, as they vary among surface, intermediate depth, and deep geologic GTCC LLW disposal alternatives. The bases for this comparison were developed from the characteristics of the disposal alternatives described in Section 1.2 and the social and institutional issues characterized in Section 4. The relative differences, real or perceived, (or lack thereof) that exist for each issue across the disposal alternatives are described and a relative ranking of the disposal alternatives for a given issue provided. The section concludes with a summary discussion in Section 5.3 , which presents the overall ranking of the disposal alternatives by social and institutional issues.

\subsection{Social and Economic Issues}

The following sections compare the surface, intermediate depth, and deep geologic disposal alternatives against the following social and economic issues:

- Property Values

- Local Revenues

- Infrastructure and Services

- Employment

- Local Economy

- Sense of Community

- Equity of Risks and Benefits

- Quality of Life

- Process Defensibility.

\subsubsection{Property Values}

As discussed in Section 4.1.1, the effect of a GTCC LLW disposal site on property values likely will vary over the lifecycle of the facility. Typically, during the siting and licensing phases, a real or perceived decrease in values can be expected, followed by a potential increase during construction and operations as new permanent workers move into the area. Localized negative effects on property values may occur in those areas immediately next to the disposal site.

Given the similarities in total land area under institutional control, comparability in the visual appearance of surface facilities, and disturbance, the net effect upon property values during siting 
construction and operations would likely not vary among the disposal alternatives. The temporary housing market may be more affected by the deep geologic option due to the increased construction labor demands.

A potential property value differentiation among alternatives may occur during the closure/postclosure phase of a GTCC LLW facility. Designs for all conceptualized surface disposal facilities have some degree of surface expression, whether a structural building or earthen berm. These structures are an integral part of the surface system's performance and must be maintained in an undisturbed condition. Alternative uses for the area will be limited and physically restricted. As a result, a surface expression of the near-surface disposal alternative will be a permanent element of the visual environment posing a potential long-term impact for properties within the view of the facility.

By contrast, either the intermediate depth or deep geologic alternative, while still requiring some level of control against intrusion, will not necessarily have a visible postclosure surface expression. This lack of surface structures would less likely result in adverse impacts to property values beyond the operational life of the facility. The site could be reclaimed as a green belt or even restored for other surface uses such as grazing, or recreational use such as a park or a golf course. Depending upon the future use selected, the site could have a positive effect on the area properties following closure.

\subsubsection{Local Revenues}

Since all options would use a similar land area, it is assumed that payment in lieu of taxes by the Federal government to the state and local municipality or Indian tribe would be comparable among all disposal options, with the potential exception of slightly increased revenues that might result from the increased cost of construction of the deep geologic alternative. In any event, these payments are more likely affected by agreements reached during the siting process than by the assessed facility value. Taxes or payments in lieu of taxes, disposal fee surcharges, and other payments to local governments are not tied to the disposal alternative.

Except for the potential increase in employment during construction of a deep geologic disposal and the intermediate depth facilities, there appears to be little difference in the impact to local revenues of any of the disposal alternatives.

\subsubsection{Infrastructure and Services}

Basic long-term requirements for support from the local infrastructure and the demand for services would be characterized by the operation, closure, and postclosure periods, and would be the same for all alternatives. However, the primary economic difference among surface, intermediate depth, and deep geologic appears in the increased construction work force for the deep geologic and, potentially, the intermediate depth alternatives. Depending on the local community's ability to assimilate the temporary infrastructure demands of the construction periods, the deep geologic and the intermediate depth alternatives could produce a more severe construction phase impact.

\subsubsection{Employment}

As identified in Section 1, the deep geologic alternative and potentially the intermediate depth, would require a larger labor force during construction than that for surface. The potential positive economic impact of this requirement may be tempered somewhat by the likelihood that the local 
work force may not have the skill base needed for this specialized construction and, therefore, a higher percentage of construction jobs would go to workers outside the local community. The impact of a transient construction work force will depend primarily on the size of the local community, and is not expected to vary by disposal alternative.

\subsubsection{Local Economy}

According to the Rogers \& Associates report, payroll expenditures are expected to be highest for the deep geologic alternative, followed by the intermediate depth and then the surface alternative. Higher payroll expenditures result in greater expenditures in the local economy. Concerning nonpayroll expenditures, the magnitude of local purchases will depend largely on the area in which the facility is sited. Therefore, from a purely economic perspective, this issue would tend to favor the deep geologic alternative.

\subsubsection{Sense of Community}

As described in Section 4.1.2, the siting of a GTCC disposal facility will affect the local community's stability. However, the characteristics of such an action which would affect the community do not differ significantly among the three disposal alternatives. Community disruption during construction may be greater for the deep geologic and potentially for the intermediate depth facility because of the larger work force. Community disruption will be reduced through local hiring. To the extent that one disposal alternative requires more specialized skills than are available locally, the community experiences a greater impact. Depending upon the facility's location, this may be the case for the intermediate depth and deep geologic alternatives. From a community stability perspective, the lower temporary construction work force would favor the surface alternative. However, the more lasting effect on a community would come from operations that would not vary significantly among the disposal alternatives.

Community satisfaction will not be a factor of disposal alternative rather, it will be reflected by the role and responsibility of the local citizens in the many decisionmaking processes involving a GTCC disposal facility. Failure to promote and accept public participation in the process results in community dissatisfaction regardless of the disposal configuration. Thus, differentiation among the alternatives based on this issue is not possible.

\subsubsection{Equity of Risks and Benefits}

The real or perceived equity of risk and benefits from a GTCC disposal facility will not be driven by the choice of disposal alternative. As described in Sections 4.1 .2 and 5.1.6, this issue is driven by programmatic considerations and location-specific factors, not by disposal alternative.

\subsubsection{Quality of Life}

The effect of a GTCC disposal facility on the quality of life of the affected community is the result of direct physical and indirect psychological impacts. The direct physical impacts would not vary significantly among the three disposal alternatives; however, the psychological impacts may. For example, the physical manifestations of a surface disposal facility during the operational period may serve as a constant reminder of the perceived hazards of the site while the intermediate depth and the deep geologic alternatives lend themselves to an "out of sight - out of mind" attitude. However, such a potential advantage of intermediate or deep alternatives may be viewed as a negative by an audience focused on the issues of ease of monitoring and ability to retrieve the waste if system 
performance fails to meet expectations. Many such examples can be generated for the relative positive and negative effects of the three alternatives on public perception of quality of life; however, none lend themselves to meaningful discrimination among the alternatives.

\subsubsection{Process Defensibility}

Public acceptance of a GTCC disposal facility will in large measure be based on the perception of need for the facility, adequacy of the process to respond to public concerns, and the perceived ability of the system to adequately protect public health and welfare. The process by which a disposal alternative is selected will affect the perception of defensibility. Since performance assessment and economic analyses do not distinctly discriminate among the alternatives, the acceptability of a disposal alternative by an affected community will be most significantly affected by their participation in the process. If one alternative was technically superior to the others, then the implementation of a program directed at that alternative might be the most defensible. Studies conducted to date by Rogers \& Associates indicate no such distinctions.

\subsection{Institutional Issues}

The following sections compare the surface, intermediate depth, and deep geologic disposal alternatives against the following institutional issues:

- Technical Review Capability

- Adequacy of Regulatory Requirements

- Interface of Participants

- Emergency Response Planning

- Credibility of Participants

- Land/Water Use and Rights

- Safety

- Liability

- Financial Assurance

- Institutional Control

- Political Influences.

\subsubsection{Technical Review Capability}

One aspect of process defensibility hinges upon the credibility and capability of the individuals evaluating the performance of the facility to isolate the waste. As shown by HLW and LLW programs, this issue of credibility applies not only to the disposal facility proponent, but also to the Federal, state, or local agency or individual charged with independently assessing the analyses of the proponent. It could be argued that the added complexity of modeling the performance of either the intermediate depth or deep geologic alternatives, compared to the surface alternative, could compound the difficulty of achieving a defensible process. In addition, these nonsurface disposal alternatives would require more specialized technical expertise less likely to exist in the local community than those technical skills needed to independently assess the performance of a surface alternative.

\subsubsection{Adequacy of Regulatory Requirements}

The lack of regulatory language specific to GTCC, and the implied intent of the NRC in 10 CFR 61 to have GTCC waste disposed in a deep geologic repository, demonstrates a regulatory 
predisposition for the deep geologic alternative. As pointed out by the 1988 OTA report to Congress, An Evaluation of Options for Managing Greater-Than-Class-C Low-Level Radioactive Waste, "Given the increasing difficulty in siting nuclear waste facilities, it is unlikely that the Federal Government, presumably DOE, would choose to develop a new, separate facility for GTCC waste." This regulatory and political bias for the deep geologic disposal alternative creates a significant institutional hurdle to the selection of surface or intermediate depth alternatives.

\subsubsection{Interface of Participants}

The intermediate depth and deep geologic disposal alternatives require specialized expertise by the state and local reviewers. Additionally, if a state or municipality has no ongoing mining activity, the basic regulatory expertise, requirements, and permitting agencies may not exist. If state and local review of a GTCC project can rely upon existing agency expertise, as would be more likely for the surface alternative, the public acceptance of the process is likely to be enhanced. However, these types of technical skills exist in the work force, and, as demonstrated by the HLW program at Yucca Mountain, can be acquired by the agencies to support their technical needs. Even so, the availability of applicable expertise would tend to favor the surface alternative for most locations.

\subsubsection{Emergency Response Planning}

The most significant element of emergency response planning for a GTCC facility is training and equipping communities that could be potentially affected by transportation accidents. These needs are independent of the disposal alternative. Emergency response planning would only be relevant to the choice of alternatives if the disposal alternative effected the choice of shipping mode or container, which it does not. Thus, there is no current basis for differentiating among alternatives on this issue.

\subsubsection{Credibility of Participants}

As discussed in Section 5.2.3, the surface alternative would be most easily addressed by existing expertise in state and local agencies. These individuals may be viewed by the public as more credible than newly hired consultants that may be required for the intermediate depth and deep geologic alternatives. The issue of credibility is not otherwise sensitive to the differences among disposal alternatives.

\subsubsection{Land/Water Use and Rights}

Regulatory requirements will necessitate long-term control over land and water use over and potentially around a GTCC disposal site regardless of the disposal alternative selected. This control will extend to subsurface features such as ground water and mineral resources. However, as noted in Section 5.1.1, the intermediate depth and deep geologic alternatives provide options for the longterm use of the land surface that would not be viable for a surface facility. Land uses such as a green belt, park, or golf course, which could be viable for intermediate and deep alternatives, would be seen as positive long-term impacts to the community as opposed to the monolithic structures associated with the surface alternative. It is highly likely that all disposal alternatives would have similar restrictions on subsurface use. 
It is assumed that land acquisition provisions similar to those in 10 CFR 60.121, 10 CFR 61.14(a), or 61.59(a) would apply to a GTCC disposal facility regardless of disposal alternative. The provisions would require that the Federal government own the land used for a GTCC disposal facility.

By design, both intermediate depth and deep geologic alternatives provide greater protection from accidental intrusion with less institutional control than does the surface alternative. Because of the intrinsic control from inadvertent intrusion and the potential opportunity for future land uses of the site surface, this issue would tend to favor the intermediate and deep geologic alternatives.

\subsubsection{Safety}

Short-term safety concerns relate to worker and public protection during construction and operations. Long-term safety concerns are specific to the performance of the facility and its ability to prevent unacceptable exposures to the public. Because of the increased hazards inherent in subsurface development, the intermediate depth and deep geologic alternatives pose a greater threat to worker safety than a surface facility. Actual risk to the public during operations may not vary among alternatives; however, perceived risk to the public would likely be greater for a surface facility due to the proximity of the waste.

Long-term performance as a surrogate for public risk was evaluated by Rogers \& Associates (RAE-9208/1-2), and found to vary among alternatives based on location-specific characteristics. For the public, the successful resolution of the issue of long-term safety of a GTCC disposal site will be more than a programmatic demonstration of performance and a regulatory concurrence. It will involve demonstration of the validity of the performance standards as a measure of adequate safety. And it will include a judgment of the capability of the individual participants from both the applicant and the regulators. All disposal alternatives would have to undergo the same level of public scrutiny and skepticism.

\subsubsection{Liability}

Under all three alternatives, the Federal government will ultimately be liable for the short-term and long-term costs associated with GTCC disposal. Disposal fees may affect long-term costs; however, the taxpayer ensures the funding for long-term performance. Among the disposal alternatives, the potential to incur costs from facility failures may be higher for the surface alternative because potential intrusion is more likely than intermediate or deep configurations. However, the liability associated with the cost for retrieval in the event of facility failure would be much higher for the intermediate depth and deep geologic after closure. Given these pros and cons, this issue does not tend to discriminate among alternatives.

\subsubsection{Financial Assurance}

As characterized in Section 4.2.9, the Federal government, through DOE, will be solely responsible for establishing and maintaining mechanisms to ensure the financial viability of the project throughout construction, operations, closure, and postclosure institutional monitoring.

The greater potential need to guard against inadvertent intrusion into a surface facility may increase the costs of long-term institution control, over that which would be required for the intermediate depth and deep geologic alternatives. 


\subsubsection{Institutional Control}

The concept of deep geologic disposal relies upon the expectation that the geologic media of the disposal alternative will behave in the future as it has over the years since its emplacement. As such, monitoring of the waste after disposal is neither envisioned nor feasible. At intermediate depth, it would also be difficult to monitor long-term performance. This alternative relies more on facility performance by structures and waste packaging. The surface alternative, while also relying on system performance, affords the greatest opportunity for long-term environmental monitoring of the system. The ability to monitor would favor the surface option, however, the lack of need for long-term monitoring favors the intermediate depth and deep geologic alternatives. As noted in Section 4.2.10, the monitoring requirements for GTCC are unclear. As LLW, it would be required to be monitored throughout the institutional control period, which could last up to 100 years. As HLW, it would have to retrievable for 50 years after emplacement, with no definitive monitoring requirements after that period. Therefore, at this time environmental monitoring does not serve as a discriminator among alternatives.

\subsubsection{Political Influences}

No amount of technical evaluation, analytical study, public participation, independent oversight, institutional interaction or program credibility can overcome the reaction of politics to the siting of a GTCC LLW disposal facility. As shown by the termination of the first and second repository programs through amendments to the National Waste Policy Act, politicians are capable of significant action to prevent the disposal of radioactive waste within the backyards of their constituents. As suggested by the OTA Report to Congress, any choice other than GTCC disposal in the Yucca Mountain HLW repository will be an uphill institutional and political battle (OTA, 1988).

The Federal budgetary processes by which a GTCC disposal program would be implemented would not vary among the disposal options. Limitations placed by the budget process on program funding, regulatory oversight, independent review, and public participation have occurred in previous Federally funded radioactive waste programs, and they can be expected for a GTCC program. However, the reality of this situation will be driven by political, social and institutional factors and not the specific choice of disposal alternative.

Past and current radioactive waste programs serve as excellent examples of the effect of political, private, and public lobbying on the success of radioactive waste projects. Lobbying will be a factor in a GTCC program. History shows that no constituency will want such a facility, and therefore will employ all available means to defeat such a proposal. Because of the regulatory and political bias toward deep geologic, described in Section 4.2.2, the surface and intermediate depth alternatives would have an increased difficulty in gaining acceptance.

Similar to lobbying efforts, opponents of a GTCC facility will use every means to defeat the proposal. For example, the State of Nevada legislatively banned the HLW repository, and on that basis, denied needed permits to the DOE for exploration studies. After several years of unsuccessful negotiation, the DOE had to seek resolution in the courts. Such tactics can be anticipated for a GTCC facility regardless of its specific configuration: surface, intermediate depth, or deep geologic.

The dynamics of the interactions between elected officials and their constituents regarding nuclear waste is a unique phenomenon in the social-political arena. Regardless of politicians' personal perspectives of the potential long-term economic benefit that could be realized by a community or state from a radioactive waste disposal facility, be it HLW, LLW, or GTCC, their public position will 
predictably be opposition. However, this posturing will occur in a GTCC project regardless of the choice of disposal alternatives; therefore, this issue does not discriminate among alternatives.

\subsection{Conclusions}

The comparisons provided in Sections 5.1 and 5.2 do not provide significant distinction among the surface, intermediate depth, and deep geologic disposal alternatives. Social and institutional issues would be oriented to disposal of GTCC waste and not the specifics of disposal depth. Aspects of disposal such as the waste package, depth, overpacking, etc., are relevant components of performance; however, social and institutional issues are not sensitive to this level of disposal detail. Social and institutional issues are affected by such factors as public participation and physical, emotional, and economic impacts. Social and institutional issues would be subject more to the characteristics of the community than to the technical elements of GTCC waste disposal. For example, a GTCC waste disposal project would be much less disruptive to the social and institutional character of a large municipality than it would be to a small rural community.

Often the issues are offsetting. For example, the larger the disposal project, the higher the increase in property values, local revenues, employment and local economy. Conversely, larger projects result in increased pressure on the infrastructure, higher demands on social services, and a greater potential effect on the quality of life and sense of community. Again, these issues and their offsetting nature depends on the size of the community.

Of the 20 social and institutional issues discussed in Sections 5.1 and 5.2, nine issues provide no distinction among the surface, intermediate depth and deep geologic alternatives. These nine issues are: equity of risks and benefits; quality of life; process defensibility; emergency response planning; safety; liability; financial assurance; institutional control; and political influences. This neutrality among disposal alternatives should not be interpreted as insensitivity to GTCC waste disposal. These issues will be significant influences on the conduct of a GTCC waste disposal project, regardless of the selected disposal alternative.

For most potential sites, the surface disposal alternative would be favored only by the issues of technical review capability and interface of participants. This conclusion is based on the perspective that the added complexity and specialized expertise required for the subsurface activities of the intermediate depth and deep geologic alternatives may not be commonly available in either state or local regulatory agencies. Deep boring or mining activities required by the intermediate depth and deep geologic alternatives are not common activities to many regulatory agencies or communities and, therefore, to interact technically with a GTCC disposal project, new expertise would be required. Surface disposal design and construction activities would not represent a unique activity to most regulatory agencies, and most communities would have available expertise to effectively interact with a surface GTCC waste disposal project. When new expertise in-migrate to a community, credibility of participants would become an issue.

The surface alternative would be the least favorable in the context of the current body of regulations affecting GTCC waste disposal. The LLW disposal regulations, 10 CFR 61, clearly favor the deep geologic alternative and place a significant burden of proof on DOE to demonstrate the viability of any other disposal alternative.

The intermediate depth and the deep geologic alternatives are more favorable than the surface alternative for property values, local revenues, employment, local economy, and land/water use and rights. Because the intermediate depth and deep geologic alternatives would employ a larger 
construction work force, the monetary benefit to the local community would be higher than that for a surface facility. However, the potential short-term financial benefit from the transient construction work force could be an impact on the community's infrastructure and social services. Additionally, since the influx of transient workers can impact a community's stability, cohesion, and general sense of community, the larger work force required for the intermediate depth and deep geologic alternatives could be a disincentive for these alternatives.

In the long term, because the intermediate depth and deep geologic alternatives would not necessarily have surface expressions of the facility after closure, adjacent property value impacts may be less than for the surface alternative. The lack of long-term surface structures for the intermediate depth and deep geologic alternatives also creates the potential for surface land uses, such as green belts and recreational uses, which may not be feasible for a surface facility.

In summary, while the comparisons of disposal alternatives by issues in this section noted some subtle potential differences among the disposal alternatives, none were significant enough to support a choice of one alternative over the others. Further, because the impact of a GTCC waste disposal facility would vary significantly among locations, even the subtle differences noted could be nonissues for a given location. 


\section{RECOMMENDATIONS FOR ADDRESSING SOCIAL AND INSTITUTIONAL ISSUES}

This section presents recommendations for addressing social and institutional issues related to a GTCC waste disposal facility. The following sections present five categories of recommendations, with suggestions on addressing specific issues during the lifecycle of the facility.

- Address Issues Through Siting Criteria: Siting criteria that tend to reduce the magnitude of social and economic impacts should be explicitly incorporated into the site selection process. Screening sites on the basis of explicit social and economic factors has not been done extensively in the past because there are few regulations to address social and economic concerns. Also, siting factors are often contradictory. For example, to address social disruption from the influx of new workers, a site with larger, more diverse population should be sought. But to minimize potential risk-related concerns such as property value, a site at a smaller, more remote location should be sought. A more detailed discussion of the consideration of issues during siting is provided in Section 6.1.

- Develop an Impact Alleviation Plan: DOE should negotiate a package with the local community to mitigate economic and social impacts and provide additional benefits as incentives for facility acceptance. This plan would be developed in the siting and licensing phase of a GTCC waste disposal project, with specific components to address issues during construction, operation, closure, and postclosure phases of the project. A more detailed discussion of an impact alleviation plan is provided in Section 6.2.

- Develop a Public Education and Involvement Program: DOE should develop a wellconceived public involvement program to address the lack of trust by providing the public direct access to and influence on the decisionmaking process. The more informed the local public, the more thoughtful their evaluation of the risks and benefits of the proposed facility. The current siting problem is related to distrust in decision-makers and decisionmaking processes more than in a lack of information. The public involvement process will be most critical in siting, but should extend through each lifecycle phase for the facility. The challenge will be to identify and involve all concerned publics in a fair and effective process. A more detailed discussion of issue resolution through public education and involvement is provided in Section 6.3.

- Use Good Management Practices: In each phase of a GTCC waste disposal program, DOE and its contractors should manage under the philosophy of accountability to the local community to build a positive track record for the facility. A problem contributing to the existing stigma toward radioactive waste disposal facilities has been the high profile of problem sites, where accidents occurred or communities protested against unresponsive management. A recent analysis on the closure of CNSI's low-level radioactive waste disposal facility in Barnwell found that most residents view the company and facility as a good neighbor. This attitude is a result of CNSI's public relations program as well as the overall pronuclear attitude in the community. Recommendations for key elements of good management practices is provided in Section 6.4.

- Establish an Institutional Framework: A key factor in obtaining the overall acceptance of a GTCC waste disposal facility, and especially generating and maintaining the public confidence, will be establishing a credible, well understood institutional framework within which the facility can be sited, licensed, built, operated, closed, and overseen in the postclosure period. 
This framework comprises a set of applicant, governmental, regulatory, financial, and emergency response organizations that can demonstrate competency and credibility in their roles relative to the disposal facility. Examples of the importance of these institutional components include regulators with the expertise and funding to provide meaningful oversight, financial sureties for long-term postclosure care and monitoring, and adequate emergency planning and response capability. Since some of these objectives may not be realized within many local and state governments, federal assistance may be warranted in the form of financial aid or technical support to responsible parties at the local level. A more detailed discussion of individual issues factoring into the institutional role and recommendations relative to them is provided in Section 6.5.

\subsection{Address Social and Economic Issues Through Siting Criteria}

Siting criteria can be used to address the social and economic issues concerning property values, employment, local economy, infrastructure and services, sense of community, and quality of life. Table 6-1 identifies measurable criteria to address social and economic issues during the siting phase of a GTCC waste disposal project. A discussion of the rationale for the criteria follows.

Concerns about property values relate to the stigma of being near a perceived high-risk facility. Therefore, siting criteria to address real or perceived adverse effects on property values should focus on distancing the facility from people.

To address both the impacts of employment and the associated issues regarding changes within the community, develop siting criteria to minimize the in-migrant work force for the facility. During construction and operation, reducing the need for in-migrants will reduce community disruption. To accommodate this objective, criteria should focus the decision on sites that have a qualified existing labor force nearby. Siting criteria may also be used to promote local benefits from nonpayroll expenditures by locating the facility where some support industries, such as concrete suppliers, already exist.

Siting criteria should be used to reduce the need for additional infrastructure and services to serve the facility and the incoming work force. Areas that already have available housing, roads, schools, police, sanitation, and social services would be the least impacted from a GTCC waste disposal facility. Of these, perhaps housing is the most important consideration in the siting criteria, as social disruption will be minimized if there is available housing with existing infrastructure already integrated into the community. Communities concerned about a declining tax base would see the facility as a benefit compared to areas with more vibrant economies.

Since some of the criteria are conflicting, applying the types of criteria listed in the table would result in a range of different siting opportunities for analysis. For instance, some criteria would lead toward remote unpopulated areas while others would favor developed communities with existing infrastructure and labor force. As described in Section 6.3, Public Education and Involvement, public process involving different social, economic, political, and geographical interests to refine the criteria and assess the criteria's relative importance should be implemented before site selection. 
Table 6-1. Potential siting criteria to address social and economic issues.

\begin{tabular}{|c|c|c|}
\hline Issue & Measurable Criteria & Example Siting Criteria \\
\hline Property Values & $\begin{array}{l}\text { Avoid residences } \\
\text { Avoid population centers } \\
\text { Minimize effects on } \\
\text { development } \\
\text { Use available lands efficiently }\end{array}$ & $\begin{array}{l}\text { Locate a site at least } 1 \mathrm{mi} \text { from any residence } \\
\text { Locate a site at least } 30 \text { min from any urban area } \\
\text { and } 5 \text { mi from any town center } \\
\text { Locate a site free from encumbrance by growth } \\
\text { and development in the region around the site } \\
\text { Identify a proposed site that is more valuable as a } \\
\text { GTCC LLW disposal site than any other use }\end{array}$ \\
\hline Local Revenues & $\begin{array}{l}\text { Maximize relative value of local } \\
\text { economic benefits }\end{array}$ & $\begin{array}{l}\text { Consider jurisdictions that need or are looking for } \\
\text { additional revenues }\end{array}$ \\
\hline Infrastructure and Services & $\begin{array}{l}\text { Minimize need for public } \\
\text { improvements }\end{array}$ & $\begin{array}{l}\text { Site in areas where major additions to housing, } \\
\text { public infrastructure and local services would not } \\
\text { be necessary }\end{array}$ \\
\hline Employment & $\begin{array}{l}\text { Minimize influx of construction } \\
\text { workers } \\
\text { Maximize local hiring in } \\
\text { construction and operation } \\
\text { Minimize effect of influx of } \\
\text { workers on community }\end{array}$ & $\begin{array}{l}\text { Restrict siting to locations where the in-migrate } \\
\text { construction work force would not increase local } \\
\text { population by over } 10 \% \\
\text { Restrict siting to locations where there is available } \\
\text { labor in construction and hazardous/radioactive } \\
\text { waste related occupations } \\
\text { Site near a larger, more diverse communities with } \\
\text { demographic and socioeconomic characteristics } \\
\text { similar to those of incoming work force }\end{array}$ \\
\hline Local Economy & $\begin{array}{l}\text { Maximize local economic } \\
\text { benefits }\end{array}$ & $\begin{array}{l}\text { Site near communities with existing potential } \\
\text { support businesses, such as research facilities, } \\
\text { engineering firms, and materials manufacturing } \\
\text { Avoid sites with agriculture/industries that are } \\
\text { more likely to be associated with stigma effects, } \\
\text { such as agriculture and food processing or } \\
\text { packaging } \\
\text { Avoid areas highly dependent on tourism }\end{array}$ \\
\hline Sense of Community & Minimize social disruption & $\begin{array}{l}\text { Site near larger, more diverse communities with } \\
\text { demographic and socioeconomic characteristics } \\
\text { similar to those of in-migrating population } \\
\text { Site in areas that would not require substantial } \\
\text { increases in housing } \\
\text { Site in areas with experience in responding to } \\
\text { population changes }\end{array}$ \\
\hline Equity of Risks and Benefits & $\begin{array}{l}\text { Match benefits to impacts } \\
\text { Minimize the proliferation of } \\
\text { waste facilities }\end{array}$ & $\begin{array}{l}\text { Favor proximity to large waste generators } \\
\text { Use an existing government facility with radioactive } \\
\text { or hazardous wastes }\end{array}$ \\
\hline Quality of Life & $\begin{array}{l}\text { Minimize risk-related concerns } \\
\text { Minimize number of people with } \\
\text { risk-related concerns }\end{array}$ & $\begin{array}{l}\text { Site at least } 1 \mathrm{mi} \text { from any residence } \\
\text { Site in areas that already have experience with } \\
\text { hazardous or radioactive waste facilities } \\
\text { Site at least } 30 \text { min from any urban area and } 5 \mathrm{mi} \\
\text { from any town center }\end{array}$ \\
\hline Process Defensibility & Minimize community opposition & $\begin{array}{l}\text { Avoid areas that have rejected proposed nuclear } \\
\text { power plants or hazardous waste facilities }\end{array}$ \\
\hline
\end{tabular}




\subsection{Develop an Impact Alleviation Plan}

An impact alleviation plan provides a mechanism to mitigate potential adverse social and economic impacts from the facility and provide benefits to the local community. The plan can also be used to enhance a host community's perception that risks and benefits are equitable. The plan should be designed with local input to address site-specific issues and solutions. As used in this report, local community refers to the potentially affected area; this may include several political jurisdictions.

It will be important to correctly assess the potential impact area so that the flow of costs and benefits across jurisdictional boundaries is fair. Local input should also include different segments of the population to minimize the extent to which the interests of one sector, like real estate development, are met at the expense of others, such as the elderly and others on fixed incomes. The limits of the facility's contribution to the local economy should be established so there is a balance among costs to federal taxpayers, generators of GTCC waste and their customers, and the benefits to the local community. This upper limit of the facility's contributions may be based on a percentage of total development costs. A summary of recommended measures for DOE to address specific mitigation and incentive issues is presented in Table 6-2.

\subsubsection{Property Values}

A property value monitoring program would help address local fears regarding adverse property value effects by monitoring sales data before, during, and after facility development. The program would include a control area to assess the effects of the GTCC waste disposal facility operation relative to other market factors. An annual report would be produced by DOE to inform the community of the results. A property value support program could be negotiated with the local community/landowners in advance, to protect them from adverse impacts. Several factors would need to be assessed to isolate the effect of the facility on property values and evaluate just compensation, including:

- differences between actual sales or asking price compared to fair market value

- duration of sales effort

- distance of property from the facility

- length of time since the facility was sited

- health and safety record of the facility.

\subsubsection{Local Revenues}

Many mechanisms exist to provide local revenues to mitigate the cost of additional infrastructure and services, and provide net fiscal benefits to local jurisdictions. These include disposal fee surcharges, payments in lieu of taxes, and gross receipts of taxes. The significance of these payments depends upon their magnitude, duration, and effect upon the community in terms of new business activity or enhanced social conditions. Concerning duration, an important factor will be whether the funds are available when they are needed. Since the GTCC waste disposal facility will be federally owned, direct payments, such as those proposed for the MRS volunteer sites, should be considered. 
Table 6-2. Potential impacts alleviation plan components.

Issue

Property Values

Local Revenues

Infrastructure and Services

Employment

Local Economy

Sense of Community

Equity of Risks and Benefits

Quality of Life

Process Defensibility
Plan Component

Establish land value monitoring program and annually report to the community

Establish property value support program

Provide disposal fee surcharges to provide state or local revenues

Provide payments in lieu of taxes

Buy locally to contribute to local gross receipts taxes

Advance payments or loans for up-front investment in infrastructure and services

Provide facility support services

Provide local training for construction and operations employment

Support training programs in local schools and universities

Scholarship program with facility employment contingency

Commit to hire locally for qualified labor

Provide retraining/adult education programs to help employees find employment following facility closure

Commit to maximize local purchases where goods and services are available locally

Establish economic development trust fund/grants to provide local employment opportunities after closure

Commit to maximize local hiring during construction and operation

Coordinate transportation of outside workers

Provide financial or in-kind support of local civic organizations

Support retraining programs to help people stay in the community following closure

Support business development programs to encourage new businesses after closure

Provide funding/in-kind support for community enhancement projects such as a park or seniors center

Provide grants for independent technical review

Sponsor educational curricula in the schools

Provide open process for involving different segments of the population in impacts alleviation plan and benefit discussions 


\subsubsection{Infrastructure and Services}

While the total population influx from the facility is likely to be small, the following infrastructure and services will be needed:

- housing

- road improvements

- police

- social services

- schools

- public services.

An accurate assessment of the nature and timing of facilities and services will be important to timing the availability of funds for improvements in advance of need. The typical boom-town phenomenon should be avoided of having increased revenues occur too late to meet the need for local improvements. Facility employees may be able to support local government services for shortterm needs, such as may occur during construction.

\subsubsection{Employment}

The objective of many of the employment mitigation and benefits measures is to maximize local hiring. An alleviation plan should consider employing locals at several skill levels, beginning with a commitment to a hiring preference for available local unskilled workers. For more skilled positions, including those requiring knowledge of health and safety provisions, establishing training programs for locals would help prepare them for these positions. For areas with strong labor unions, training could be provided through the union. Finally, since the higher paying positions may require a college, graduate, or postgraduate education, a program could be established to provide scholarships to local residents who would commit to returning to the local community and working at the facility for a period of time.

Before facility closure, an assessment of local re-employment opportunities could be conducted and appropriate training or adult education provided to help facility workers stay in the local community. This kind of training program would be best coupled with an economic development program discussed in the following section.

\subsubsection{Local Economy}

Purchases of goods and services locally can produce a substantial economic benefit to the local economy without the associated fiscal burden of in-migrants. However, where facilities are located in remote areas, it is unlikely that major suppliers of equipment and materials will be local. At a minimum, commitments should be made to purchase office equipment and supplies and other materials available locally. Facility investments in related support industries that would remain following closure help diversify the local economy. Alleviation plans should consider businesses that may be adversely affected by the facility and develop mechanisms to reduce potential impacts, such as grants for advertising local tourist opportunities.

Providing adequate advanced planning for economic diversification upon closure is important. In addition to training, the plan could include setting up a trust fund at the start of facility operation 
to provide seed grants or loans for new businesses. Business development programs could be supported to diversify the local economy after closure.

\subsubsection{Sense of Community}

Minimizing adverse effects on the cultural traditions and lifestyles of residents in the local community is best accomplished by maximizing local hiring, thus reducing the influx of newcomers to the area. Where workers can commute from larger urban centers, facility programs to provide worker transportation to the site can help minimize impacts on the local community.

During construction and operation, the facility can have a positive impact socially by providing funding to, and encouraging employees to get involved in, civic organizations. Upon closure, programs to minimize migration out of the area, such as retraining and business development programs, can help reduce social disruption.

\subsubsection{Equity of Risks and Benefits}

Most of the impact alleviation plan will address how to provide economic and social benefits to the local community. For those who receive jobs or have additional business, the benefits are real. Some residents, such as the elderly and others on fixed incomes, will not realize these benefits. In fact, if competition for workers leads to rising prices, these residents could find it more expensive to live in the area. Funding for community enhancement programs that benefit these people, such as senior centers, medical services, and parks, can provide benefits for this segment of the population. Some people may perceive that the facility will adversely affect them economically while representing an economic boom to the rest of the community. Examples include farmers, businesses dependent upon tourism, and small businesses that may be displaced by larger chains. While there are always disproportional losses and gains from any economic change, involving people who fear economic losses in discussing the impact alleviation plan and benefits package may lead to ideas on how to reduce potential or perceived impacts to these sectors.

\subsubsection{Quality of Life}

Addressing risk-related concerns requires responding to public fears that the facility may endanger their health and well-being and that of future generations. The perception of a risk adversely affects how comfortable people are in the community and their perceived quality of life. Most of the measures to address these fears relate to local education programs and involving people in facility decisions. From the standpoint of local community benefits and impact alleviation, grants to both local government and organizations to fund independent risk assessments are probably most effective. Sponsoring school curricula to provide education on risks for school-age children is also recommended.

\subsubsection{Process Defensibility}

Involving all elements of the public in discussing the impact alleviation plan is important to negotiate a fair plan that matches mitigation to impacts and does not favor one segment of the population or jurisdiction over another. As discussed in the preceding sections, a fair process is a key ingredient for public acceptance and process defensibility. 


\subsection{Develop a Public Education and Involvement Program}

Emotional responses to risk typically decrease as people understand more about risk through education. Therefore, an effective program to help people understand the risks of the facility will be an essential component of the facility's social and institutional program. But, education alone is not enough. By involving people in the decisionmaking process, they are forced to confront societal trade-offs. People confront their own zero risk or we-want-it-all expectations by learning about how their demands affect the needs of others. Education moves people with different interests toward a common goal to balance those interests. This section recommends mechanisms for public education and involvement.

\subsubsection{Public Education}

Recommendations for public education about a GTCC waste disposal facility focus primarily on the siting process. One suggestion is to fund a neutral party to develop and distribute public information. For instance, the Illinois Department of Nuclear Safely (IDNS) funded the League of Women Voters to develop factual information. Since today's society is characterized by information overload, the education program must try to reach people where they will be most receptive to the message. Different segments of the community, from school children to seniors, should be targeted as well. The goal will be to demystify radioactive waste disposal. Educational mechanisms that make the facility real and help people visualize what their community will be like with the facility will be most effective. Suggestions include field trips, science fairs, and interpretive centers.

\subsubsection{Public Involvement}

Given the findings of this report, it appears warranted to consider siting a GTCC waste disposal facility only at federal facilities with radioactive or hazardous waste experience and volunteer host areas. However, designating these sites as candidates from the start, without public input in reaching this conclusion, could fuel local opposition to the effort because people in these communities may perceive that they are the unfairly designated disposal area for the rest of the nation. This is similar to the response from the state of Nevada to the HLW repository. Therefore, the recommended public process should first identify broad candidate areas with the understanding that it may lead to consideration of only federal facilities or volunteer communities. While it is not within the scope of this report to develop a public involvement program for GTCC facility siting, an overall framework for public involvement in siting follows.

Concerning the public's involvement in a siting program, four principles should be followed:

1. The public will not accept a siting process without having some influence upon it.

2. The process should begin with a clear understanding of:

- Who the public is -- anyone who may be (or perceives they may be) affected by the facility, what their concerns are

- What the public expectations are for involvement in the siting effort.

3. The program should be tailored to the local area; although the general issues will remain the same, the relative importance of specific issues can vary significantly by community. 
4. The public involvement process will change in both technique and focus at different stages in siting.

The siting process can be characterized by three distinct phases:

- Identification of Regional Siting Areas

- Site Identification

- Site Characterization.

A public involvement program must continuously evolve as the decision process moves forward. The following discussions summarize the recommended approaches to each phase.

Identification of Regional Siting Areas - A cornerstone of effective compromise in a public involvement program is agreement on need. The lack of a national consensus on need for waste disposal facilities has resulted in failed siting efforts as local opposition overwhelms national need.

It is recommended to begin the siting process for GTCC waste disposal by involving national and local interests in designing a fair siting process. During the first stage in siting, a broad range of candidate areas should be considered. Diverse areas, representing distinct choices from a social and institutional perspective, should be considered. The siting process should begin with a wide range of choices so that different options can be overtly evaluated.

Site Identification - Once specific sites are identified, local residents that are impacted should be identified immediately and consulted on how they would like to be involved in the decisionmaking process. Ideally, agreement among the different areas on criteria to be used to evaluate the sites would be secured.

In some instances, site selection has been oriented toward competition among potential host communities. This approach was successfully applied in siting a hazardous waste incinerator in Canada several years ago. While some communities have volunteered to be considered for disposal sites for radioactive waste, politics have always intervened. Public acceptance of a siting process with explicit ground rules that minimize political influences will be an important element in the siting process.

Site Characterization - Sites should be evaluated based on criteria developed through a public process and representatives of the different sites involved in reviewing results. At this time, potential components of, and limits to, the impact alleviation plan and benefits package would be discussed. The specific package would vary by community.

Lacking a clear technical preference among GTCC disposal alternatives, local input on technologies may also be sought and may become the discriminating factor in selecting a disposal option. One community may favor deep disposal with future visions of a golf course, while another prefers surface disposal for easier access in the event of future problems.

While public education and involvement will be most critical in facility siting, maintaining open information channels and local oversight throughout the lifecycle of a GTCC facility will be important as well. Good management practices to build and maintain a positive track record in the community are discussed in the following section. 


\subsection{Use Good Management Practices}

Good management practices demonstrate the facility's responsiveness to the community and to high standards of performance during construction, operation, and closure. The objective is to build a positive track record to help build and maintain public trust. As expressed by Luther Carter, "Trust will be gained by building a record of sure, competent, open performance that gets good marks from independent technical peer reviewers and that shows decent respect for the public's sensibilities and common sense" (Slovic et al. 1991). Potential measures to build and maintain a positive reputation in the community include:

- Responding promptly and openly to requests for information

- Providing regular review of the impact alleviation plan and revising it to reflect changing conditions, including independent peer review

- Investing in the economic diversity of the community

- Implementing policies favoring employee involvement in community affairs

- Funding civic organizations and community events

- Enforcing strict oversight and control of all operations to protect public health and safety.

Of these measures, the last is most important. Protection of the public health and safety is essential. To establish this as a priority at the facility, management performance evaluations for both private operators and DOE personnel should include a mechanism for evaluation of attention to health and safety provisions in design, construction, operation and closure. An incentive program for employees to be diligent in following health and safety procedures and responding to the public may also be effective.

\subsection{Establish an Institutional Framework}

This section discusses the following issues relevant to establishing an institutional framework for a GTCC waste disposal site. These issues are:

- Technical Review Capability

- Adequacy of Regulatory Requirements

- Interface of Participants

- Emergency Response Planning

- Credibility of Participants

- Land/Water Use and Rights

- Safety

- Liability

- Financial Assurances

- Institutional Control

- Political Influence. 


\subsubsection{Technical Review Capability}

Public confidence requires that the agencies and individuals who oversee a GTCC waste disposal facility have adequate expertise and authority to meaningfully influence how the facility is developed. Because some state and local agencies may not have the specialized expertise required, the DOE should consider supplying funds to achieve this objective. Cooperative efforts with local universities should be investigated as well as making available national independent scientific resources (for example, National Academy of Sciences). These measures will ensure that there is no lack of qualified participants on both sides of the regulatory process and that the regulators themselves have both the appearance and substance of technical expertise that matches that of the applicant.

\subsubsection{Adequacy of Regulatory Requirements}

As with regulatory expertise, public confidence requires an adequate body of regulations and regulatory standards to govern the GTCC waste disposal effort. Although a considerable body of HLW and LLW regulations have been promulgated, the issue of where a stand-alone GTCC waste disposal facility fits within this framework may require some attention within the public information/public involvement program. Of particular importance will be demonstrating to the public that issues such as public heath and safety, institutional control periods, regulatory agency roles and authority (including regulatory overlap), and environmental monitoring are adequately addressed. Overall recommendations on the public involvement program were presented in Section 6.3.

\subsubsection{Interface of Participants}

A major lesson learned from earlier siting efforts for controversial facilities is that a meaningful opportunity for involvement by all concerned parties in the facility development process must be provided. Dimensions of this problem include the participation of federal, state, local, and tribal authorities as well as technical, regulatory, political, and public participation. Since even the best of regulatory frameworks do not always address local concerns of such parties, specific components of the public education/public involvement program should consider providing forums or other mechanisms to accomplish this goal. Workshops, advisory boards, town meetings, and newsletters are among the techniques that can be used to accomplish this objective.

\subsubsection{Emergency Response Planning}

In view of intense public concern about both operational and transportation accidents, it will be extremely important for the GTCC waste disposal facility proponent to ensure that adequate capability exists for planning and executing emergency response actions at the facility and along transportation routes. Since such capability may not already exist in the GTCC waste disposal facility area, it may be necessary to implement a program to enhance the capability of local emergency response agencies. Included in this arena may be response planning capability, evacuation capability, personnel training, facility (for example, hospital) upgrades, equipment purchase, and funding for training exercises. The public information/public involvement program should be designed to maximize the public confidence benefit from these community enhancement activities.

\subsubsection{Credibility of Participants}

Establishing a clear need for the facility is one of the most critical components in the establishing credibility with the public. Contributing to this problem is a public perception that waste sites are proliferating more on the grounds of commercial opportunity or governmental intransigence than on 
real need. Particularly important for a GTCC waste disposal facility will be a clear demonstration that a facility separate from the HLW repository is actually required. It is recommended that an advisory task force review the rationale for a GTCC waste disposal facility in the context of the overall national radioactive waste program to ensure that a credible rationale can be presented to the public. This result should be prominently incorporated into the public information/public involvement program.

\subsubsection{Land/Water Use and Rights}

Control of land and water use within the GTCC disposal facility boundary is critical to the waste containment performance objectives. As is required by 10 CFR 60 and 61, it is recommended that fee simple ownership of a GTCC disposal site by the Federal government is the most effective, most credible way to accomplish these goals. However, the government may wish to evaluate other possibilities in conjunction with negotiation of the local compensation plan. Clearly, land and water rights must also be under the control of the facility proponent. Additional control over offsite water use, if dictated by environmental monitoring results, may also be appropriate. Any arrangement other than fee simple ownership must be evaluated in light of the ability to legally maintain control over all activities in and around the site for the full institutional control time period.

\subsubsection{Safety}

Two aspects of safety are relevant: Worker safety and public health and safety. Adequate measures to protect each of these populations are mandated by law and by regulation; the latter also includes controls during the institutional control period. Each of these aspects of facility development must be thoroughly incorporated into the public information/public involvement program so that public confidence can be maintained. Additional potential subjects for this effort are site security, access control, intruder defense, performance standards, institutional controls (postclosure), and worker safety programs.

\subsubsection{Liability}

Public confidence requires a perception that the facility proponents (for example, owner, operator, and transporter) are clearly liable for the safe operation and closure of a waste disposal facility. The public must believe that the responsible parties are both willing to and capable of making good any detrimental environmental or health effects that could result from the facility. This, in turn, requires a stable, credible organization and financial assurances (discussed below). Since the GTCC waste disposal facility is likely to be government owned, particular attention will have to be paid to this problem.

\subsubsection{Financial Assurances}

Much of the concern regarding waste facilities focuses on the ability to provide long-term assurances of continued isolation of wastes, and in the case of GTCC well into future generations. During the institutional control period, the scope of activity required to accomplish this goal includes decommissioning, closure, maintenance, custodial care, and environmental monitoring. An ability to respond to unforeseen events (such as waste form failure or degradation) must be available as a contingency. Any affected public will recognize that significant financial resources will be required to cover these scope items and will want to avoid any situation where the local community has to bear these costs. Thus, provision of financial vehicles whereby the necessary funds will be available when needed will be a critical element in achieving public acceptance of a waste facility. Given public 
skepticism about the potential for future congressional funding changes, specific sinking funds, bonds, trusts, or other financial vehicles should be established before facility operation.

It is recommended that a financial assurance task force, comprising qualified members of the banking, securities, and accounting industries, be convened to establish appropriate funding surety vehicles before starting the siting process. Additional members from the affected community should be added to the task force at completion of siting so that local concerns, as applicable, can be reflected in the nature and content of financial surety agreements.

\subsubsection{Institutional Control}

As discussed above, institutional control, especially in the closure and postclosure periods, is essential to both the substance and perception that current and future generations are being adequately protected. Activities falling within this category include long-term environmental monitoring of the site and environs; custodial care of facilities and equipment; periodic surveillance of the site; generation and maintenance of adequate operations, closure, and monitoring records; and long-term financial assurances. The importance of these factors in gaining and maintaining public confidence is discussed above in the context of other issues; however, it is important to note that creation of a stable entity (for example, government corporation or agency) that will clearly survive through the postclosure period will be essential to demonstrating overall institutional control.

\subsubsection{Political Influence}

In terms of incorporating the views of interested parties into the decision processes, the issue of political influence is discussed in Section 6.3. That discussion includes participation by agencies and other interest groups as well as regulators and the public as a whole. All parties must have confidence that the agreements reached and commitments made at the site selection and licensing phases will survive through the closure and postclosure periods. Accordingly, the overall enterprise must be set up in a way such that political influences cannot obviate the institutional foundation on which the facility's success is based. 


\section{CONCLUSIONS}

The historical perspective in Section 3 provided useful insight to the past and current programs attempting to solve the problems of HLW and LLW disposal programs. The evaluation of the programs demonstrates that social and institutional issues have been commonly omitted from siting activities. Section 3 demonstrates that frequently, the failure to adequately consider social and institutional issues into a HLW or LLW project is a contributing factor to the project's lack of success.

The scope of social and institutional issues that will affect a GTCC waste disposal program was characterized by the issues identified and discussed in Section 4 . The discussion was grouped into nine categories of social issues, and eleven categories of institutional issues. Issue characterization was based on the historical perspective provided by Section 3, available literature, the experience of the authors, and the applicable regulatory language. The issues characterized in Section 4 were then used to evaluate disposal alternatives in Section 5 and recommend actions for implementation in a GTCC waste disposal program provided in Section 6.

Section 5 compared the disposal alternative in the context of the social and institutional issues identified in Section 4. The purpose of the evaluation was to determine whether the selection of a disposal alternative would be affected by social or institutional issues. The comparison did not significantly distinguish among the surface, intermediate depth, and deep geologic disposal alternatives. The evaluation clarified that social and institutional issues would be oriented to disposal of GTCC waste and not the specifics of disposal depth.

Of the 20 social and institutional issues discussed in Section 5, 9 issues provided no distinction among the surface, intermediate depth, and deep geologic alternatives. For most potential sites, it was determined that the surface disposal alternative would be favored only by the issues of technical review capability and interface of participants. The surface alternative would be the least favorable in the context of the current body of regulations affecting GTCC waste disposal. The LLW disposal regulations, 10 CFR 61, clearly favor the deep geologic alternative and place a significant burden of proof on DOE to demonstrate the viability of any other disposal alternative. The intermediate depth and the deep geologic alternatives are also more favorable than the surface alternative for property values, local revenues, employment, local economy, and land/water use and rights.

Although the comparisons of disposal alternatives by issues in Section 5 noted some subtle potential differences among the disposal alternatives, none were significant enough to support a choice of one alternative over the others. Further, because the impact of a GTCC waste disposal facility would vary significantly among different locations, even the subtle differences noted could be nonissues for a given location.

Section 6 presented recommendations for addressing social and institutional issues throughout the lifecycle of a GTCC waste disposal program. The five categories of recommendations were:

- Address Issues Through Siting Criteria

- Develop an Impact Alleviation Plan

- Develop a Public Education and Involvement Program

- Use Good Management Practices

- Establish an Institutional Framework. 
Within each category of recommendation, methods and processes are provided by which the issues identified in Section 4, could be successfully integrated into the conduct of a GTCC waste disposal program. The recommendations draw significantly from the successes and failures of the HLW and LLW programs, the experiences of the authors who were involved in radiological waste disposal programs, and from the open literature. 


\section{REFERENCES}

Battelle, 1989, Assessment of Issues Related to Property Values and the Development of a Low-Level Radioactive Waste Disposal Facility in Clark or Wayne County, Illinois, (Draft Report), Office of Low-Level Waste Technology Battelle Project Management Division, April 1989.

Clark, Luther J., 1987, Nuclear Imperatives and the Public Trust, Washington, D.C., Resources for the Future, Inc.

Code of Federal Regulations, 10 CFR 60, "Disposal of High-Level Radioactive Wastes in Geologic Repositories," Office of the Federal Register, January 1993.

Code of Federal Regulations, 10 CFR 61, "Licensing Requirements for Land Disposal of Radioactive Waste," Office of the Federal Register, January 1993.

Covello, V., 1991, Factors Contributing to Public Perceptions of Trust and Credibility, Columbia University, 1991.

East Carolina University, 1989, Low-Level Radioactive Waste Management: An Impact Study On Site Selection, Regional Waste Management Task Force, March 1989.

English, M. R., 1991, The Economic and Social Impacts of Chem-Nuclear's Low-Level Radioactive Waste Disposal Facility on Barnwell County, South Carolina, Energy, Environment and Resources Center, University of Tennessee, Knoxville, January 1991.

EPA, 1979, Siting of Hazardous Waste Management Facilities and Public Opposition, U.S. Environmental Protection Agency, 1979.

ERM-PMC, Inc. and Rogers \& Associates Engineering Corporation, 1992, Initial Source Term Characteristics for Analysis of GTCC Disposal Alternatives, EG\&G Idaho, Inc., December 1992.

Harvard Law School, 1984, Public Disputes Program of the Program of Negotiation, Radwaste Siting Game I.

IDNS, 1993, Low-Level Radioactive Waste Compacts Status, Illinois Department of Nuclear Safety, February 1993.

Kasperson, Roger, 1988, Assessing the Social and Economics Impacts of a Low-Level Radioactive Waste Disposal Facility in Illinois, Center for Technology, Environment, and Development, Clark University, Prepared for Illinois Department of Nuclear Safety, February 1988.

Rogers \& Associates Engineering Corporation, 1993, Technically Feasible Systems for the Disposal of Greater-Than-Class-C Low-level Radioactive Waste, Draft for Review (RAE-9208/1-2), February 1993.

Slovic, Paul, M. Layman, and J. H. Flynn, "Lessons From Yucca Mountain," Environment, Volume 33 Number 3, April 1991, pp. 7-30. 
U.S. Congress Office of Technology Assessment, 1988, An Evaluation of Options for Managing Greater-Than-Class-C Low-Level Radioactive Waste, October 1988.

U.S. Nuclear Regulatory Commission, Office of Nuclear Material Safety and Safeguards, "Licensing Requirements for Land Disposal of Radioactive Waste." Draft Environmental Impact Statement on 10 CFR Part 61, Summary, NUREG-0782, September 1981.

U.S. Nuclear Regulatory Commission, Office of Nuclear Material Safety and Safeguards, "Licensing Requirements for Land Disposal of Radioactive Waste." Final Environmental Impact Statement on 10 CFR Part 61, Summary and Main Report, NUREG-0945, November 1982.

Wright, S., 1991, "The NIMBY Syndrome: Environmental Failure and Credibility Gap," Hazardous Material Control, March/April 1991. 